\title{
Determining the Role of Hotel Attributes in Building Customer Loyalty Using Importance-Performance Analysis: A Study in the Context of Tourist Nationalities
}

\author{
Engin Üngüren \\ Alanya Alaaddin Keykubat University, Alanya, Turkey \\ Salih Tellioglu \\ Alanya Alaaddin Keykubat University, Alanya, Turkey \\ Nazlı Türker \\ Alanya Alaaddin Keykubat University, Alanya, Turkey
}

Received: 13 January 2021. Revision received: 25 March 2021. Accepted: 3 May 2021

\begin{abstract}
Identifying the importance and satisfaction of hotel attributes in the eyes of tourists and their role in building customer loyalty is critical for improving the service quality. Therefore, in our study, customers' importance and performance perceptions regarding the services offered by accommodation businesses were examined in terms of customers' nationalities. Our research has two main objectives. The first objective is to determine the importance and performance perceptions of the services provided by the hotels according to the nationalities of the customers using the using importance-performance analysis (IPA) model and to compare the perceptions of importance-performance according to nationality. The second aim is to determine the effect of satisfaction perceptions regarding hotel services on customer loyalty according to customer nationality. The research was designed as a survey-based quantitative research methodology. Convenience sampling was used, which is a non-random sampling method. Data were obtained from 1153 German, Russian, and Turkish tourists accommodating in five-star hotels in Alanya, Turkey. A gap analysis was conducted using pairwise t-tests to evaluate whether the importance and performance perceptions of the participants differed. IPA was conducted with attributes being graphically displayed on the I-P grids. The impact of hotel service satisfaction on customer loyalty was investigated using regression analysis. The research findings reveal that customers' performance perceptions and services attach importance to differ significantly by nationality. And also, it was concluded that satisfaction with the services provided in accommodation businesses has a significant effect on customer loyalty and that this effect differs in customer groups. Determining satisfaction factors affecting customer loyalty according to customer characteristics make a significant contribution to service quality improvement. In this context, the research results provide practical and theoretical contributions to how customer satisfaction and customer loyalty can be improved according to market groups.
\end{abstract}

Key Words: Customer satisfaction, customer loyalty, importance-performance analysis, hotel attributes

JEL Classification: Z31, Z33

Reference: Üngüren, E., Tellioglu, S. \& Türker, N. (2021). Determining the Role of Hotel Attributes in Building Customer Loyalty Using Importance-Performance Analysis: A Study in the Context of Tourist Nationalities. Journal of Tourism and Services, 22(12), 105-130. doi: 10.29036/jots.v12i22.237

\section{Introduction}

The hospitality industry is highly competitive, and customer satisfaction is vital in industries where competition is high and essential for business survival (Cheng et al., 2019; Liat et al., 2017; Wilkins, 2010; Unguren \& Arslan, 2021). Also, increasing customer satisfaction is a prerequisite for developing strategies 


\section{JOURNAL OF TOURISM AND SERVICES}

Issue 12, volume 22, ISSN 1804-5650 (Online)

www.jots.cz

that help businesses to position themselves competitively. Thus, customer satisfaction has been the main goal of businesses that aim to be successful and that want to continue their existence in the long term (Agyeiwaah et al.,2016; Cobanoglu et al. 2011; Bosque \& Martín, 2008; Kobylanski, 2012). Customer satisfaction is also a way to ensure the financial stability of businesses (Maroco \& Maroco, 2013). In short, customer satisfaction is critical to competition and significantly affects the customer's choice of hotels and destinations.

Previous studies have revealed a strong relationship between customer satisfaction and customer loyalty (Deng \& Pierskalla, 2018; Jin et al. 2008; Maroco \& Maroco, 2013; Tanford, \& Jung, 2017; Yang et al., 2014). The loyal customer creates an emotional bond with the business and prefers the same business, even though there are many other competing businesses in an intensely competitive environment (Yoo \& Chang, 2005). Loyal customers have low price sensitivity, tend to buy more, recommend the business to their environment, and significantly increase profitability (Wilkins, 2010). Besides, the fact that acquiring new customers is much more costly than keeping customers on board (Bowen \& Shoemaker, 1998) demonstrates the importance of customer loyalty. It is not possible to build customer loyalty without achieving customer satisfaction. Customer retention has to do with the maintenance of the bond between the business and customer (Gerpott et al., 2001). Customer loyalty, on the other hand, refers to the buyer's intention to purchase the same or different services from the current supplier in future. In addition, a loyal customer also tends to recommend the supplier to others as well (Cahill et al., 2010). Therefore, customer satisfaction is a prerequisite for customer retention and customer loyalty (Maroco \& Maroco, 2013; Sarwar et al., 2012).

In order for accommodation businesses to keep their customers satisfied, it is essential that a business knows to what aspects customers attach importance and how the business performs in relation to these (Wilkins, 2010). Therefore, it is of strategic importance to determine which attributes are perceived as important by customers and the performance perceptions of customers regarding these attributes (Chu \& Choi, 2000). It is also significant for managers to identify services that are found to be of great importance in terms of customer satisfaction and to improve these services. Nevertheless, since operational resources are limited, managers often find it difficult to decide which areas to improve (Albayrak \& Caber, 2011). An analysis method exists (Jin, Qi \& Chiang, 2008) that provides managers with valuable information on both customer satisfaction measurement and efficient allocation of resources in an easily applicable format. Importance-performance analysis (IPA), first developed by Martilla and James (1977), defines which product or service qualities a business should focus on to increase customer satisfaction (Blešić et al. 2014).

This research was carried out in the Alanya region of Turkey. Alanya is one of the most important international destinations of the Mediterranean, with an area of $1,879 \mathrm{~km}^{2}$ and a beach of $70 \mathrm{~km}$ long. There are, in total, 631 touristic facilities in Alanya. These facilities have a total of 82,350 rooms and 180,202 beds. In 2019, a total of 6,693,646 tourists, of whom 5,825,161 were foreigners and 868,485 were locals, visited Alanya (ALTSO, 2020). Considering the distribution of visitors to Alanya by nationality in 2019, Russians (2.482.480 people) ranked first, Germans (932.300 people) second, and Turks (868.485 people) third (ALTSO, 2020). Alanya has seasonal tourism, and tourism generally starts in April and continues until the end of November. The highest density is experienced in July-August. During the winter months, most of the accommodation facilities are closed. Although the number of tourists coming to Alanya increases every year, Alanya faces serious competition from nearby countries and regions. Besides, the yearly increase in the number of accommodation businesses in the region causes intense competition among businesses. Hotel businesses in Alanya compete with their rivals by following a lowprice policy. However, the key factor for an accommodation business to differentiate itself from its competitors and create customer loyalty should be service quality, not price (Kandampully \& Suhartanto, 2000; Maroco, \& Maroco, 2013; Nobar \& Rostamzadeh, 2018). Accommodation businesses operating in Alanya are required to continuously improve their service quality to achieve a competitive advantage and 


\section{JOURNAL OF TOURISM AND SERVICES}

Issue 12, volume 22, ISSN 1804-5650 (Online)

www.jots.cz

to provide services according to the needs and requests of customers to increase customer satisfaction and loyalty.

Many studies in the tourism literature have examined the performance and importance levels of products or services using IPA (Abooali et al., 2015; Chu \& Choi, 2000; Mohsin et al., 2019; Sharma et al., 2018). A few researchers attempted to link IPA with overall satisfaction in a structural equation model (SEM) or used regression analysis to test the relationships between attributes in each IPA quadrant with overall satisfaction. IPA implies that attribute performance will have little influence on overall satisfaction when self-stated importance is low. However, this assumption has rarely been tested in the literature (Deng \& Pierskalla, 2018). Therefore, our study aims to contribute to this issue, and to this end two main objectives were identified. The primary objective of our research is to determine the importance and performance perceptions of the services provided by the hotels according to the nationalities of the customers using the IPA model and to compare the perceptions of importance-performance according to nationality. The results obtained in our study can significantly assist managers in creating market segments. Defining customer groups that demand a particular product or service plays a crucial role in market positioning. Analyzing the importance and performance perceptions in terms of different segments can help hoteliers develop marketing strategies to meet the needs of each segment (Blešić, et al., 2014).The second main objective of our study is to determine the effect of satisfaction perceptions regarding hotel services on customer loyalty according to customer groups. The diversity of tourists' perceptions of satisfaction with a tourism service is based on their countries of origin (Agyeiwaah et al., 2016). For this reason, not every product and service offered by hotels during tourists' stay may contribute equally to overall customer satisfaction and customer loyalty (Deng \& Pierskalla, 2018). Also, satisfaction factors that affect customer loyalty may be different according to the characteristics of customers. Determining satisfaction factors affecting customer loyalty according to customer characteristics is one of the most important issues of tourism, marketing, and management (Taplin, 2013). In this context, the research questions of the study are as follows: (a) Does the level of importance given by customers to hotel services differ according to their nationality?(b) If there is a statistically significant differentiation, what are the hotel services that customers care about based on their nationality? (c) Does customers' satisfaction with hotel services differ according to their nationality? (d) Do the satisfaction factors of hotel services affecting customer loyalty differ according to the nationalities of the customers? The results obtained in this study are expected to contribute to understanding the demands and expectations of different customer segments and to enhancing customer loyalty. The rest of the article is structured to reveal, first and foremost, the conceptual framework of the study with a literature review, covering customer satisfaction, customer loyalty and importance-performance analysis. Hypotheses are then developed, based on the results of the review. The following sections include the methodology, measurement, analysis and results of the research study. The final part of the study includes the discussion of results, conclusion, implications, limitations and directions for future research.

\section{Literature review}

\subsection{Customer Satisfaction}

Today, digital technologies make it possible for people to easily access information. Customers can easily get information about businesses and their products and services (Grewal et al. 2017). As a result, rapidly developing technology and increasing competition have pushed businesses to become customer-oriented businesses where customer demands and expectations are always met. In a customeroriented business, the most important criterion of all marketing activities is considered to be customer satisfaction (Kamdanpully \& Suhartanto, 2000). Satisfaction is the feeling of meeting or exceeding the customer's expectations when a product's prepurchase expectations are compared with its postpurchase product-performance output. Customer satisfaction is an essential tool in implementing modern 


\section{JOURNAL OF TOURISM AND SERVICES}

Issue 12, volume 22, ISSN 1804-5650 (Online)

www.jots.cz

marketing thinking and improving the overall quality of life. Therefore, customer satisfaction is crucial in meeting the diverse needs of consumers, businesses, and society.

Forozia, Zadeh and Gilani (2013) concluded that customer satisfaction is a key factor that leads accommodation businesses to success and that provides a competitive advantage. Because of increasing competition due to the rapid increase in the number of accommodation enterprises (Kandampully \& Suhartanto, 2003), customer satisfaction is one of the most basic goals that accommodation enterprises want to achieve in the service process (Cobanoglu et al., 2011). The reason is that customer satisfaction is a factor that significantly affects businesses' income, enabling businesses to sustain their activities (Forozia et al., 2013). Nisar and Prabhakar (2017) concluded that customer satisfaction is also an active factor in consumers' spending. The fact that customer satisfaction is extremely important for businesses has attracted the attention of researchers, and research on this topic continues to expand (Assaf \& Magnini, 2012; El-Adly, 2019; Lahap et al., 2016; Li et al., 2013; Mohammed \& Rashid, 2018; Nunkoo et al., 2020; Sánchez-Franco et al., 2019).

Since the most important factor that increases customer satisfaction in accommodation businesses is the quality of service, businesses compete to provide better service to their customers (Davras \& Caber, 2019; Deng et al., 2013; Jeong \& Oh, 1998; Oh, 1999; Oh \& Kim, 2017; Nunkoo et al., 2020). The main purpose of accommodation businesses is to meet the service expectations of customers with different characteristics and to ensure their satisfaction because customers always want their expectations to be met; otherwise, dissatisfaction occurs. Customer satisfaction measures how well customers' expectations are met by companies (Shoemaker \& Lewis, 1999). In this context, businesses need to determine which products and attributes they should focus on according to the different customer segments to meet the expectations of their customers (Albayrak, 2015a).

\subsection{Customer Loyalty}

Briefly, customer loyalty is an emotional connection between the customer and the business (Oliver 1997). Customer loyalty is often confused with customer satisfaction, but these are different concepts. Whereas customer satisfaction expresses the degree of meeting customer expectations (Kotler et al., 2006), customer loyalty refers to the intention of customers to revisit the business, to purchase again, and to recommend the business to their environment (Yoo \& Chang, 2005; Yoon \& Uysal, 2005).

Reichheld and Sasser (1990), Gould (1995), and Reichheld (1996) have revealed that customer loyalty significantly increases the profitability of businesses. These research results increased the interest of managers and researchers in customer loyalty, and the search for information on how to achieve and increase customer loyalty has begun (Bowen \& Chen, 2001). Customer loyalty, therefore, has been considered a significant asset of an enterprise (Tsaur, Chiu, \& Huang, 2002). Thus, the issues of how to improve, maintain, and increase customer loyalty have been the main interests of managers (McCain, Jang, \& Hu, 2005). Studies in the literature suggest that customer satisfaction, in particular, should be established in order to ensure customer loyalty. Customer loyalty cannot be achieved without ensuring customer satisfaction. Thereby, customer satisfaction is the prerequisite for customer retention and customer loyalty and, at the same time, for gaining competitive advantage (Taplin, 2013; Martenson, 2007). Studies on this subject reveal that customer satisfaction increases customer loyalty (Agyeiwaah et al. 2016; Deng \& Pierskalla, 2018; Lin \& Wu, 2011; Kandampully \& Suhartanto, 2000; Maroco \& Maroco, 2013; Som et al., 2011; Olorunniwo, Hsu \& Udo, 2006; Tanford, \& Jung, 2017).

Loyal customers are unlikely to change business and move to another business because of the price factor (Bowen \& Chen, 2001). Besides, loyal customers recommend the business to others through word of mouth and direct their relatives to the business. In this respect, the digitalization of commerce and the power of social media to set the agenda have made customer comments and recommendations of critical importance. Chen (2008) stated that managers read customer reviews to reduce risks and avoid uncertainty while making the purchasing decision of customers, and they revealed that customer reviews 


\section{JOURNAL OF TOURISM AND SERVICES}

Issue 12, volume 22, ISSN 1804-5650 (Online)

www.jots.cz

are more effective than expert comments. In a study conducted by Al-Balushi and Atef (2013) in Oman, the primary source of information for $52 \%$ of the tourists coming to Muscat was found to be destination and hotel review sites.

Making existing customers loyal is much cheaper than reaching potential customers (Kim, Vogt \& Knutson, 2015). The cost of acquiring new customers is greater than the cost of retaining satisfied customers (Maroco \& Maroco, 2013). For this reason, it is important to make improvements in these areas by identifying the factors affecting customer satisfaction. Managers often find it difficult to decide which areas to improve first because their information about which product and service attributes customers pay more attention to is limited (Albayrak \& Caber, 2011). Developed by Martilla and James (1977), IPA identifies which product or service attributes are more important to customers and reveals their perception of satisfaction with these attributes. Thanks to IPA, it is possible to determine which of the attributes studied are relatively more important to customers, and effective marketing strategies can be developed by comparing the product performance associated with them.

\subsection{Importance-Performance Analysis}

By measuring the expectations of customers, it becomes possible to direct investments and services in the direction of what customers desire, allowing the formation of customer loyalty and the creation of a positive business image. Knowing which of the services offered by businesses to their customers yield more satisfaction plays a role both in improving the quality of service and in achieving the desired level of customer satisfaction. Various methods exist in the literature for measuring customer satisfaction. One of the most used methods is importance-performance analysis (IPA), which was developed by Martilla and James (1977). According to Martilla and James (1977), IPA is "a low-cost, easily understood technique that can yield important insight into which aspect of the marketing mix a firm should devote more attention as well as identify areas that may be consuming too many resources" (p. 79). Martilla and James (1977) developed this analysis as a low-cost and easily understood technique in order to determine which product and service attributes should be given importance to increase customer satisfaction in terms of marketing and to identify areas that consume more resources than needed.

In IPA, Martilla and James (1977) define customer satisfaction with two criteria. The first criterion is the importance that customers give to the product or service, and the second criterion is the performance of the relevant product or service. IPA basically seeks answers to the following two questions: How important is this attribute for customers? How high is the performance (satisfaction) regarding these attributes? (Martilla \& James, 1977). IPA is performed using a two-dimensional matrix with performance on the $\mathrm{x}$-axis and significance on the y-axis. Four quadrants emerge as a result of the analysis: Concentrate Here, Keep Up With the Good Work, Low Priority, and Possible Overkill (Martilla \& James, 1977).

Concentrate Here (high importance, low performance): Although customers consider the product or service attributes in this quadrant to be important, they perceive the performance of these attributes as low. This quadrant is regarded as the most critical one because it shows that the level of performance in the areas that customers most care about is not satisfactory (Azzopardi \& Nash, 2013).

Keep Up With the Good Work (high importance, high performance): This quadrant represents the key strengths and potential competitive advantages of the product or service. The attributes in this quadrant are perceived by customers as having both high performance and high importance. It is necessary to constantly invest in the attributes in this quadrant (Sever, 2015).

Low Priority (low importance, low performance): Both the importance attributed to the product attribute and the perceived performance level in this quadrant are found to be low (Griffin \& Edwards, 2012). A low level of performance is not an issue for managers to consider, as the product attribute in this quadrant is given low importance (Chu \& Choi, 2000). 


\section{JOURNAL OF TOURISM AND SERVICES}

Issue 12, volume 22, ISSN 1804-5650 (Online)

www.jots.cz

Possible Overkill (low importance, high performance): Customers perceive the performance of the product attributes in this quadrant as high but do not attach importance to these attributes in the selection of goods or services. The attributes in this quadrant are considered to be the ones that are oversourced (Albayrak \& Caber, 2011).

According to Martilla and James (1977), the presentation of results in the importanceperformance grid provides a convenient way of interpreting the data by management and greatly assists in making strategic marketing decisions. IPA is a method that provides a time-cost advantage, and it is easy to interpret. It also enables the development of effective management strategies when applied correctly (Griffin \& Edwards, 2012). IPA is a simple and functional tool for identifying the strengths and weaknesses of the services offered and for identifying the areas that need to be developed (Rial, Rial, Varela \& Real, 2008). One of the remarkable aspects of this analysis is that the results obtained can be converted into easy and understandable graphs (Martilla \& James, 1977). This analysis is often preferred by managers in the decision-making process, as it does not require advanced statistical analysis, can be easily interpreted, and is a cheap method to implement (Albayrak, 2015b). In the policymaking process of businesses, IPA results provide an important basis for improving overall performance by identifying priority focus areas (Cvelbar \& Dwyer, 2013). This strategic model developed by Martilla and James (1977) is considered useful since it simultaneously measures the attributes that customers care about in a product or service and their performance perception (Azzopardi \& Nash, 2013).

\section{Hypothesis Development}

\subsection{Cross-National Importance-Performance Perceptions of Customers towards Hotel Services}

Nationality, country of residence and culture are important factors in tourist satisfaction and loyalty in the tourism sector. From this perspective, a volume of noticeable research has been conducted in tourism literature. For example, Poon and Low (2005) investigated a study to understand the factors that measure different satisfaction levels between the Asian and Western travellers during their stays in Malaysian hotels. They compared Asian and Western travellers and found that hospitality is the most important factor in determining overall satisfaction levels for both groups and will contribute to revisit intentions. Pricing was found to be the most influential factor, affecting Asian travellers' satisfaction. For Western travellers, security and safety were evaluated as the two most important factors.

Kim, Lee \& Han (2019) conducted a study, which aimed to explore the tangible and intangible attributes behind hotel selection from the point of view of the local guests in the hotel industry in South Korea. Moreover, they intended to explore the role of these explored attributes in building behavioural intentions. In this research, 17 intangible hotel selection attributes and 16 tangible hotel selection attributes were scrutinized. These attributes were segmented into seven core dimensions, which included human \& environment capital, utilitarian charm, brand asset, subsidiary facilities, room features, outward appearance and additional products. Using the IPA analysis, they examined the strengths and weaknesses of each attribute in terms of the importance and satisfaction. According to results, the local guests evaluated intangible attributes as comparatively more important, but less satisfactory. However, tangible reviews were appraised as to ensure higher level of satisfaction with respect to perceived importance. Furthermore, the results illustrated that the satisfaction of intangible attributes that are likely to induce local customers' positive WOM and revisit intentions. Room features and outward appearance dimensions increased positive WOM intentions, whereas subsidiary facilities and room feature factors strengthened revisit intentions.

Kuo (2007) conducted a study about the effect of the importance of hotel employee service attitude on the satisfaction of international tourists. The survey was conducted at Chaing Kai Shek International Airport, located in northern Taiwan, and Kaohsiung International Airport, located in southern Taiwan. Customers from America, Japan, and Taiwan participated in the study. After using 


\section{JOURNAL OF TOURISM AND SERVICES}

Issue 12, volume 22, ISSN 1804-5650 (Online)

www.jots.cz

exploratory factor analysis, friendliness, empathetic feeling, enthusiastic service and problem solving were found to be the factors of the service attitude. Also, the importance-performance analysis was carried out for the importance of the employees' service attitudes and customer satisfaction. According to the results of the study, customer satisfaction regarding employee satisfaction vary significantly according to the customers' nationality. Results of the study illustrated that Japanese have the most rigid requirements for service attitude, while Taiwanese are in the middle and Americans have the least.

Emir (2013) conducted a study in a five-star hotel in Antalya (Turkey) to explore the satisfaction of tourists from six different countries (Turkey, Germany, Russia, the Netherlands, Ukraine and the United Kingdom). According to the results of analyses, satisfaction varies according to nationalities. Turkish and German customers presented the highest satisfaction levels, while Dutch and Ukrainian customers have the lowest levels of satisfaction, related to the overall services of the hotels. Ceylan, Cizel and Karakas (2020) conducted a research to analyse the role and significance of the destination attributes and the products and services provided at destinations on the destination image perception of tourists. The data were collected from British, German and Russian tourists. According to results of the study, each nation preferred Antalya as an All-Inclusive (AI) system for different reasons. Their evaluation of the varied destination depends on their nations and they considered important different attributes of an AI destination.

A study was also conducted by Bodet, Anaba and Bouchet (2015) to determine the effect of hotel service qualities of the country of residence on the contribution to consumer satisfaction. The Tetraclasse model was applied to determine the contribution of hotel features to satisfaction and to compare them for consumer segments across hotels in eight European countries. According to the results, it was revealed that hotel service qualifications are perceived differently according to the country of residence and differ between hotels. Martín, Rudchenko \& Sánchez-Rebull (2020) investigated the role of the nationality and hotel class on guests' satisfaction by using a two hotels in Saint Petersburg as a case study. Fuzzy TOPSIS method was used in this research. According to results, nationality influences the hotel guests' satisfaction. In this study, they propose some advices for managers and researchers One of them is that it is necessary to segment hotel guests according to nationalities in order to examine the preferences and satisfaction in the hotel industry. Although many studies are classified according to gender and age, they state that there are still few studies that classify according to nationalities. Based on the results of this review, the following hypothesis is proposed.

$\mathrm{H}_{0}$ : The importance and performance perceptions of the services provided by the hotels don't differ according to the nationalities of the customers.

$\mathrm{H}_{1}$ : The importance and performance perceptions of the services provided by the hotels differ according to the nationalities of the customers.

\subsection{Cross-National Effects on Satisfaction-Loyalty Relationship}

Customer satisfaction is one of the fundamental factors, ensuring the maintenance of businesscustomer relations (Rust \& Chung, 2006) and plays an important role in sustaining and improving customer relations (Bolton et al., 2014). Customer satisfaction is also the driving force behind loyalty (Faullant et al., 2008). Since the purpose of businesses in the tourism industry is to provide the best service to them in order to sustain a long-term relationship with customers (Lee \& Kim, 2020), customer satisfaction and customer loyalty are the two significant behavioural outcomes, for which any service business strives (El-Adly, 2019). Kotler et al. (2017) state that high levels of customer satisfaction lead to higher levels of customer loyalty, which causes businesses to perform better. A number of studies found positive links between customer satisfaction and loyalty (El-Adly \& Eid, 2016; Erjavec et al., 2016; Faullant et al, 2008; Shi et al., 2014). The review of studies concerning the effects of customer satisfaction on customer loyalty in the service industry reveals; Ryu et al. (2012) observed that customer satisfaction has a positive effect on loyalty behaviour in the study regarding measuring service quality in restaurants; 


\section{JOURNAL OF TOURISM AND SERVICES}

Issue 12, volume 22, ISSN 1804-5650 (Online)

www.jots.cz

Kasiri et al. (2017) found that customer satisfaction has a significant impact on customer loyalty in a study, investigating three service industries in Malaysia; Ali et al. (2018) concluded that customer satisfaction has a significant and positive effect on customer loyalty in a study conducted on theme park visitors in Malaysia and Gallarza et al. (2019) determined that customer satisfaction has a positive impact on customer loyalty in a study, examining customer value in tourism and hotel management.

Another factor, influencing the identification of customers' levels of satisfaction and loyalty, is cultural differences (McDowall \& Ma, 2010). Customers with different cultural backgrounds place different values on the same service from the same personnel and the same experience from it (Pantouvakis, 2013). The point that a nation's cultural landscape can potentially affect the possibility of generating customer satisfaction and loyalty must be taken into account by businesses (Aksoy et al., 2013). Especially those in the service industry must design their products according to certain customer characteristics and target audiences (Kasiri et al., 2017). Identifying the role cultural diversity plays in customer-loyalty bond and determining whether or not it reinforces this bond are quite important for businesses. Many studies also investigate the role culture plays on satisfaction and loyalty. For example, Hoare \& Butcher (2008) studied Chinese, Taiwanese and Hong Kongese university students, who visit restaurants in China, and found a significant and positive link between cultural values and customer satisfaction and customer loyalty. McDowall \& Ma (2010) studied foreign and domestic tourists visiting Taiwan for holiday purposes and found that cultural characteristics and demographics vary with respect to creating satisfaction and loyalty. Aksoy et al. (2013), on the other hand, investigated the impact of cultural variables on customer loyalty intentions by using data from the mobile telecommunications customers in Australia, Brasil, Canada, China, France, Spain, United Kingdom and USA, and concluded that the effect of satisfaction on loyalty is dependent on cultural differences. Finally, Pantouvakis (2013), in a study involving customers from 10 different countries, who visited the island of Crete, found that cultural differences affect satisfaction and loyalty. Drawing off on the conclusion of this study, the following hypotheses are formed.

$\mathrm{H}_{0}$ : Satisfaction perceptions of customers towards hotel services don't affect customer loyalty.

$\mathrm{H}_{2}$ : Satisfaction perceptions of customers towards hotel services affect customer loyalty.

$\mathrm{H}_{0}$ : The effect of customer satisfaction perceptions of hotel services on customer loyalty doesn't differ according to customers' nationalities.

$\mathrm{H}_{3}$ : The effect of customer satisfaction perceptions of hotel services on customer loyalty differs according to customers' nationalities.

\section{Methodology}

\subsection{Measurement}

This research was carried out with the method of quantitative research methodology. The questionnaire form was prepared in four languages: Turkish, English, German, and Russian. Because of the time and cost advantage, convenience sampling was preferred to nonrandom sampling. The research data were collected through questionnaires, which consist of three parts. The first part of the questionnaire form consists of 17 items for determining the importance and performance perceptions of the services provided by the accommodation business. In the second part of the questionnaire, there are three questions on customer loyalty, and the last part of the form includes questions on the demographics of the participants. Thirty-eight items suggested in Callan and Bowman's (2000) study were used to determine the importance that customers give to the products and services of the accommodation businesses and their perceptions of performance. First, the opinions of the sales and marketing managers of three accommodation businesses were consulted to determine whether any issues ought to be added to the 38-item scale. Eight items were added in line with the opinions of the managers. Then, a pilot 


\section{JOURNAL OF TOURISM AND SERVICES}

Issue 12, volume 22, ISSN 1804-5650 (Online)

www.jots.cz

study was conducted with 186 people of different nationalities who were staying in three five-star hotels to determine the content validity of the scale with the extra items. Attention was paid to the fact that the participants in the pilot study consisted of customers who had one or two days until check-out. After the pilot study, it was found that not all 46 items of the scale were filled in, and some items were left blank by all participants. Subsequently, the sales, marketing, and front office managers were interviewed, and the items were reduced. In the interviews with the managers, it was understood that the customers do not want to answer long questionnaires and that they want to spend more active time in the hotel as the check-out time approaches. In accordance with the suggestions of the managers, 17 items were determined that all customers can evaluate and fill in a short time. The pilot study of the 17 -item scale was conducted in a five-star hotel with the participation of 35 customers. In the second pilot study, it was observed that all questions were answered, and the final form of the questionnaire was completed. Customer loyalty, on the other hand, was measured using propositions of the action loyalty dimension of the customer loyalty scale developed by Bobalca, Gatej, and Ciobanu (2012). The study data were collected between July 2019 and September 2019, from eight five-star accommodation businesses. The questionnaires were distributed to customers with one or two days until check-out by employees of the public relations unit of the accommodation businesses. A total of 1500 questionnaires were distributed, and 1153 questionnaires were received at the end of the data collection process. The research data were collected from a total of 1153 German, Russian, and Turkish tourists staying in five-star hotels operating in the Alanya region. The reason for collecting data from these three nationalities is that they constitute the dominant market segment for the Alanya region, as explained in the Introduction. Participants' perceptions of attribute importance, performance, and customer loyalty were measured by a 7-point Likert scale $(1=$ the least important to $7=$ the most important for the importance variable, and $1=$ extremely dissatisfied to $7=$ extremely satisfied for the performance and overall satisfaction variables).

Table 1. Sample Characteristics by Nationality $(n=1153)$

\begin{tabular}{lccc}
\hline & German $(n=378)$ & Russian $(n=411)$ & Turkish $(n=364)$ \\
\hline Gender & & & \\
Female & $52.4 \%$ & $58.6 \%$ & $56.0 \%$ \\
$\begin{array}{l}\text { Male } \\
\text { Marital Status }\end{array}$ & $47.6 \%$ & & $44.0 \%$ \\
$\quad$ Single & $25.1 \%$ & $18.2 \%$ & $10.4 \%$ \\
$\quad$ Married & $74.9 \%$ & $81.8 \%$ & $89.6 \%$ \\
Age & & & \\
18-27 & $18.5 \%$ & $17.0 \%$ & $15.1 \%$ \\
$28-37$ & $37.8 \%$ & $45.0 \%$ & $35.4 \%$ \\
38-47 & $30.4 \%$ & $27.3 \%$ & $38.7 \%$ \\
48-57 & $13.2 \%$ & $10.7 \%$ & $10.7 \%$ \\
Educational Status & & & \\
Primary School & $4.0 \%$ & $5.8 \%$ & $5.2 \%$ \\
High School & $50.8 \%$ & $37.0 \%$ & $19.5 \%$ \\
Bachelor's Degree & $36.0 \%$ & $47.4 \%$ & $64.3 \%$ \\
$\quad$ Graduate Degree & $9.3 \%$ & $9.7 \%$ & $11.0 \%$ \\
Accompaniment & & & \\
Single & $9.3 \%$ & $4.4 \%$ & $0 \%$ \\
Spouse & $39.4 \%$ & $38.4 \%$ & $27.7 \%$ \\
Spouse + Children & $32.5 \%$ & $23.1 \%$ & $60.2 \%$ \\
Only Children & $0 \%$ & $4.1 \%$ & $0 \%$ \\
Friends & $18.8 \%$ & $29.9 \%$ & $12.1 \%$ \\
\hline
\end{tabular}

Source: own research 


\section{JOURNAL OF TOURISM AND SERVICES}

Issue 12, volume 22, ISSN 1804-5650 (Online)

www.jots.cz

The demographic characteristics of the participants are shown in Table 1. A total of 1153 participants with German, Russian, and Turkish nationalities are included in the research. The distributions of the three different nationalities are similar to each other. The gender distribution of the participants shows a similar distribution based on their nationalities. The majority of the participants in all three groups are female. Besides, the age distributions show a similar distribution according to nationality, with the majority being young tourists. The educational background of the participants varies according to their nationality. The majority of Turkish tourists are university graduates (64\%). Also, high school and university graduates constitute the majority of German and Russian tourists. More than half of the Turkish tourists $(60 \%)$ go on holiday with their spouses and children, while none of them go on holiday alone. The vast majority of German and Russian tourists go on holiday with their families and friends.

\subsection{Data Analysis}

Extreme outliers were identified using the Mahalanobis distance. The normality of the data was checked by skewness and kurtosis, and then these values were analyzed. It was found that the skewness and kurtosis values were between -1.5 and +1.5 . Since the skewness and kurtosis values were within the values of a normal distribution, the normal distribution assumption was met (Kline, 2011; Tabachnick \& Fidell, 2013). A demographic profile of the respondents was examined with frequency and percentage distributions according to nationality. To evaluate whether the importance and performance perceptions of the participants differed, a gap analysis was conducted using pairwise t tests. An analysis of variance (ANOVA) was applied to determine how importance and performance scores differ by nationalities. The effect size was calculated to determine whether the differences between the results of the groups were significant. Cohen's d was used for the evaluation of the results of the pairwise $t$ tests, and eta-squared $(\eta 2)$ effect-size values were used for the ANOVA analysis results. Then, IPA was conducted, with attributes being graphically displayed on the I-P grids. The IPA matrix was constructed for the three nationality groups separately. The effect of satisfaction with hotel services on customer loyalty was tested with regression analysis. In determining whether hypotheses are supported and not supported were used $\mathrm{p}<0.05$ as significance value.

\section{Results}

\subsection{Gap Analysis}

GAP analysis indicates to what extent customers are satisfied with the issues they attach importance to. It is desirable that the performance is greater than importance. Otherwise, it points to customer dissatisfaction. Table 2 shows the results of the paired-sample $t$ test of the differences between the performance and importance perceptions of the participants according to their nationalities. According to the paired-sample $t$ tests, the means from the respondents' importance and performance were significant for each of the items. The employees' attitude and behaviour, hygiene and cleanliness, and the design and comfort of the rooms are of the highest importance to the participants from all three nationalities. Other issues they attach importance to differ by nationality. It was found that the performance scores of the participants differ by their nationalities. Although the results of the pairedsample $t$ test showed statistically significant differences between the performance and importance scores, Cohen's d effect-size values were calculated to understand the effect size. The effect size is small if Cohen's d value is less than 0.2 , medium if it is 0.5 , and large if it is greater than 0.8 . Accordingly, there is a significant and large difference between importance and performance in Turkish customers. The performance score of Turkish customers, in particular, is lower than their importance scores. This reflects that the tendency of dissatisfaction is more common among Turkish customers than among the other 


\section{JOURNAL OF TOURISM AND SERVICES}

Issue 12, volume 22, ISSN 1804-5650 (Online)

www.jots.cz

nationalities. It is undesirable in terms of customer satisfaction that there is a difference of over -2 between the issues that Turkish customers attach most importance to (employees' attitudes and behaviours, hygiene and cleanliness, the design and comfort of the rooms). The differences between the importance and performance scores of the German and Russian customers are low. These results indicate that German and Russian customers have higher customer satisfaction than Turkish customers. More detailed results are presented from IPA.

Table 2. Paired-Sample t-tests Between Performance and Importance

\begin{tabular}{|c|c|c|c|c|c|c|c|c|c|c|c|c|c|c|c|}
\hline & \multicolumn{4}{|c|}{ German $(n=378)$} & \multicolumn{6}{|c|}{ Russian $(n=411)$} & \multicolumn{5}{|c|}{ Turkish $(n=364)$} \\
\hline & $\mathrm{P}$ & $\mathrm{I}$ & Gap (P-I) & $\mathrm{t}$ & $\mathrm{d}$ & $\mathrm{P}$ & $\mathrm{I}$ & Gap (P-I) & $\mathrm{t}$ & $\mathrm{d}$ & $\mathrm{P}$ & I & Gap (P-I) & $\mathrm{t}$ & $\mathrm{d}$ \\
\hline $\mathrm{F} 1$ & 5.48 & 6.91 & -1.44 & $23.32^{*}$ & 1.7 & 5.44 & 6.91 & -1.46 & $27.79^{*}$ & 1.9 & 4.74 & 6.96 & -2.22 & $15.74^{*}$ & 1.9 \\
\hline $\mathrm{F} 2$ & 5.69 & 5.63 & 0.06 & -1.20 & & 5.78 & 5.15 & 0.63 & $-14.53^{*}$ & .90 & 5.32 & 5.89 & -0.57 & $23.92^{*}$ & 0.87 \\
\hline F3 & 5.68 & 5.57 & 0.11 & $-2.66^{*}$ & .15 & 6.12 & 6.09 & 0.03 & $-0.88^{*}$ & .04 & 5.5 & 5.33 & 0.17 & $11.61^{*}$ & 0.21 \\
\hline $\mathrm{F} 4$ & 5.34 & 5.82 & -0.48 & $10.35^{*}$ & .66 & 5.59 & 6.02 & -0.43 & $9.90^{*}$ & .05 & 4.43 & 6 & -1.57 & $-3.11^{*}$ & 1.6 \\
\hline F5 & 5.32 & 5.08 & 0.23 & $-5.61^{*}$ & .43 & 5.62 & 6.11 & -0.49 & $15.63^{*}$ & .82 & 5.48 & 5.36 & 0.12 & $22.45^{*}$ & 0.19 \\
\hline F6 & 4.65 & 4.8 & -0.16 & $3.27^{*}$ & .21 & 4.72 & 5.36 & -0.64 & $12.21^{*}$ & .88 & 4.76 & 5.81 & -1.04 & $-2.53^{*}$ & 1.1 \\
\hline F7 & 4.79 & 5.13 & -0.34 & $9.12^{*}$ & .62 & 5.08 & 5.87 & -0.79 & $17.62^{*}$ & 1.0 & 4.51 & 5.98 & -1.47 & $19.59^{*}$ & 1.7 \\
\hline F8 & 5.5 & 5.76 & -0.26 & $6.80^{*}$ & .31 & 5.76 & 5.96 & -0.2 & $5.17^{*}$ & .28 & 4.2 & 5.81 & -1.62 & $22.45^{*}$ & 1.4 \\
\hline F9 & 4.99 & 3.07 & 1.92 & $-43.39^{*}$ & .32 & 5.18 & 5.34 & -0.16 & $4.37^{*}$ & .29 & 4.76 & 4.37 & 0.38 & $20.66^{*}$ & 0.62 \\
\hline F10 & 5.09 & 5.92 & -0.83 & $18.16^{*}$ & 1.4 & 5.08 & 6.13 & -1.06 & $28.85^{*}$ & 1.6 & 4.92 & 5.8 & -0.88 & $-8.10^{*}$ & 1.2 \\
\hline F11 & 5.1 & 5.03 & 0.07 & -1.78 & & 5.2 & 4.83 & 0.37 & $-8.49^{*}$ & .60 & 4.39 & 5.41 & -1.02 & $17.21^{*}$ & 1.2 \\
\hline F12 & 5.3 & 6.54 & -1.24 & $16.96^{*}$ & 1.6 & 5.66 & 6.64 & -0.98 & $13.81^{*}$ & 1.1 & 4.62 & 6.84 & -2.22 & $15.93^{*}$ & 1.8 \\
\hline F13 & 5.66 & 5.82 & -0.16 & $3.66^{*}$ & .25 & 5.01 & 4.14 & 0.87 & $-16.13^{*}$ & 1.9 & 5.11 & 5.77 & -0.66 & $23.06^{*}$ & 1.0 \\
\hline F14 & 4.94 & 2.28 & 2.67 & $-61.49^{*}$ & 4.3 & 5.1 & 2.79 & 2.31 & $-62.83^{*}$ & 4.3 & 4.8 & 4.32 & 0.49 & $15.01^{*}$ & 0.95 \\
\hline F15 & 4.57 & 3.85 & 0.72 & $-15.89^{*}$ & 1.0 & 4.54 & 5.03 & -0.49 & $13.90^{*}$ & .97 & 4.38 & 5.24 & -0.86 & $-15.81^{*}$ & 1.2 \\
\hline F16 & 5.87 & 6.79 & -0.91 & $20.02^{*}$ & 1.5 & 6.04 & 6.41 & -0.37 & $7.63^{*}$ & 1.1 & 4.67 & 6.77 & -2.1 & $17.53^{*}$ & 1.9 \\
\hline F17 & 5.04 & 5.12 & -0.08 & 1.52 & & 4.96 & 5.7 & -0.74 & $15.74^{*}$ & 1.1 & 4.9 & 5.1 & -0.2 & $23.39^{*}$ & 0.34 \\
\hline $\begin{array}{l}\text { F1: } \\
\text { servi } \\
\text { F12: } \\
\text { clean } \\
* \mathrm{p}<\end{array}$ & $\begin{array}{l}\text { esign } \\
\text { hess } \\
05\end{array}$ & ees' at & ude and & havior & 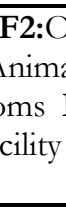 & nen b & fet & 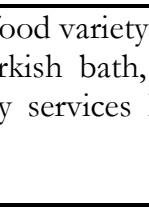 & F3:Beve & & ariet & F4: & stauran & rvices $\mathbf{F}$ & 5:Bar \\
\hline
\end{tabular}

Source: own research

Table 3.Importance-Performance Scores of Customers by Nationalities

\begin{tabular}{|c|c|c|c|c|c|c|c|c|c|c|c|c|}
\hline & \multicolumn{6}{|c|}{ Importance } & \multicolumn{6}{|c|}{ Performance } \\
\hline & German & Russian & Turkish & $\eta^{2}$ & $\mathrm{~F}$ & $\mathrm{p}$ & German & Russian & Turkish & $\eta 2$ & $\mathrm{~F}$ & $\mathrm{p}$ \\
\hline $\mathrm{F} 1$ & 6.91 & 6.91 & 6.96 & 0.006 & 3.264 & 0.039 & 5.48 & 5.44 & 4.74 & 0.058 & 35.29 & 0.000 \\
\hline $\mathrm{F} 2$ & 5.63 & 5.15 & 5.89 & 0.224 & 185.50 & 0.000 & 5.69 & 5.78 & 5.32 & 0.053 & 32.19 & 0.000 \\
\hline $\mathrm{F} 3$ & 5.57 & 6.09 & 5.33 & 0.201 & 144.70 & 0.000 & 5.68 & 6.12 & 5.50 & 0.095 & 60.43 & 0.000 \\
\hline $\mathrm{F} 4$ & 5.82 & 6.02 & 6.00 & 0.02 & 11.81 & 0.000 & 5.34 & 5.59 & 4.43 & 0.205 & 148.56 & 0.000 \\
\hline F5 & 5.08 & 6.11 & 5.36 & 0.317 & 266.61 & 0.000 & 5.32 & 5.62 & 5.48 & 0.053 & 31.88 & 0.000 \\
\hline F6 & 4.80 & 5.36 & 5.81 & 0.271 & 213.97 & 0.000 & 4.65 & 4.72 & 4.76 & 0.004 & 2.23 & 0.108 \\
\hline F7 & 5.13 & 5.87 & 5.98 & 0.266 & 208.48 & 0.000 & 4.79 & 5.08 & 4.51 & 0.08 & 50.06 & 0.000 \\
\hline F8 & 5.76 & 5.96 & 5.81 & 0.013 & 7.62 & 0.001 & 5.50 & 5.76 & 4.20 & 0.316 & 265.35 & 0.000 \\
\hline F9 & 3.07 & 5.34 & 4.37 & 0.695 & 1312.76 & 0.000 & 4.99 & 5.18 & 4.76 & 0.092 & 58.06 & 0.000 \\
\hline F10 & 5.92 & 6.13 & 5.80 & 0.055 & 33.39 & 0.000 & 5.09 & 5.08 & 4.92 & 0.011 & 6.63 & 0.001 \\
\hline F11 & 5.03 & 4.83 & 5.41 & 0.096 & 61.34 & 0.000 & 5.10 & 5.20 & 4.39 & 0.237 & 178.98 & 0.000 \\
\hline
\end{tabular}




\section{JOURNAL OF TOURISM AND SERVICES}

Issue 12, volume 22, ISSN 1804-5650 (Online)

www.jots.cz

\begin{tabular}{|c|c|c|c|c|c|c|c|c|c|c|c|c|}
\hline F12 & 6.54 & 6.64 & 6.84 & 0.049 & 56.74 & 0.000 & 5.30 & 5.66 & 4.62 & 0.11 & 71.05 & 0.000 \\
\hline F13 & 5.82 & 4.14 & 5.77 & 0.687 & 1260.37 & 0.000 & 5.66 & 5.01 & 5.11 & 0.112 & 79.99 & 0.000 \\
\hline F14 & 2.28 & 2.79 & 4.32 & 0.695 & 1308.29 & 0.000 & 4.94 & 5.10 & 4.80 & 0.051 & 30.73 & 0.000 \\
\hline F15 & 3.85 & 5.03 & 5.24 & 0.488 & 548.38 & 0.000 & 4.57 & 4.54 & 4.38 & 0.017 & 9.88 & 0.000 \\
\hline F16 & 6.95 & 6.92 & 6.96 & 0.007 & 4.09 & 0.017 & 5.87 & 6.04 & 4.67 & 0.187 & 132.56 & 0.000 \\
\hline F17 & 5.12 & 5.70 & 5.10 & 0.184 & 129.58 & 0.000 & 5.04 & 4.96 & 4.90 & 0.007 & 3.88 & 0.021 \\
\hline
\end{tabular}

F1:Employees' attitude and behavior F2:Open buffet food variety F3:Beverage variety F4: Restaurant services F5:Bar services F6:Aquapark F7:Pool F8:Animation F9:Turkish bath, spa, massage F10:Beach F11:Children's activities F12:Design and comfort of the rooms F13: Security services F14:Parking F15:Internet access F16:Hygiene and cleanliness F17:Landscaping of the facility

Source: own research

According to the results of the ANOVA in Table 3, the customers' importance and performance scores differ statistically by nationality. The effect size $(\eta 2)$ of these differences is higher for importance scores than for performance scores. Therefore, the difference in importance scores by nationality is more distinct than the difference in performance scores by nationality For example, bath, spa, and massage activities are attributes that German customers $(\mathrm{M}=3.07)$ do not attach importance to, while they are relatively important to Turkish customers $(\mathrm{M}=4.37)$ and important to Russian customers $(\mathrm{M}=5.34)$. This result shows that the issues that customers attach importance to are quite different according to the market segments. Across different market segments, the effect size between customers' performance scores is relatively small. German and Russian customers' average performance scores are close to each other but higher than those of Turkish customers. For example, the number of attributes with a performance score of 5 and above is 12 for German customers, 14 for Russian customers, and only 4 for Turkish customers. It is understood that Turkish customers are satisfied only with food and beverage services and security practices, but their satisfaction with other services is lower. These results are in support of hypothesis H1.

\subsection{Importance-Performance Analysis (IPA)}

The IPA matrix was constructed separately for each nationality (Fig. 2). The results of the IPA are plotted in the IPA grid to graphically compare the importance and performance of attributes of services offered by the accommodation businesses. The mean of the importance and performance scores in the IPA matrix is calculated separately, and the intersection point of their axes is determined (Martilla \& James, 1977). However, in general, it is at the discretion of the researcher or manager at what point the axes intersect (Albayrak \& Caber, 2011). In this regard, the opinions of the sales and marketing managers of the accommodation businesses were asked. As a result of the interviews, the values shown below were based on an average value of 5.30 for performance and 4.5 for importance (score range $=$ [highest value - lowest value] / 7 = 0.85) (1-1.85: completely dissatisfied / important; 1.86-2.71: mostly dissatisfied / important; 2.72-3.57: somewhat dissatisfied / important; 3.58-4.43: neither satisfied nor dissatisfied / important; 4.44-5.29: somewhat satisfied / important; 5.3-6.15: mostly satisfied / important; 6.16-7.00: completely satisfied / important). A 45-degree diagonal is also used to evaluate the IPA matrix. The graph is divided into two equal parts, with a horizontal diagonal drawn from the points where the importance and performance values are equal. Elements placed above the diagonal have a negative discrepancy (performance $<$ importance), whereas elements placed below the diagonal have a positive discrepancy (performance $>$ importance) (Rial et al., 2008).

\subsubsection{Keep Up the Good Work}

The attributes in the Keep Up With the Good Work quadrant reveal that they are perceived as very important by customers and that, at the same time, accommodation businesses perform relatively well. When the hotel services in this quadrant are examined, it is seen that German and Russian tourists share the same characteristics. Employees' attitude and behavior, hygiene and cleanliness, design and 


\section{JOURNAL OF TOURISM AND SERVICES}

Issue 12, volume 22, ISSN 1804-5650 (Online)

www.jots.cz

comfort of the rooms, restaurant services, animation, buffet food variety, and beverage variety are of high importance to German and Russian tourists, and their perception of performance for these characteristics is relatively high. Thus, employees' attitude and behavior, hygiene and cleanliness, the design and comfort of the rooms, and the performance of the food and beverage services should preferentially be maintained, and the resource transfer should be continued to increase the performance related to these attributes.

Figure 1. Importance-Performance matrix by nationalities
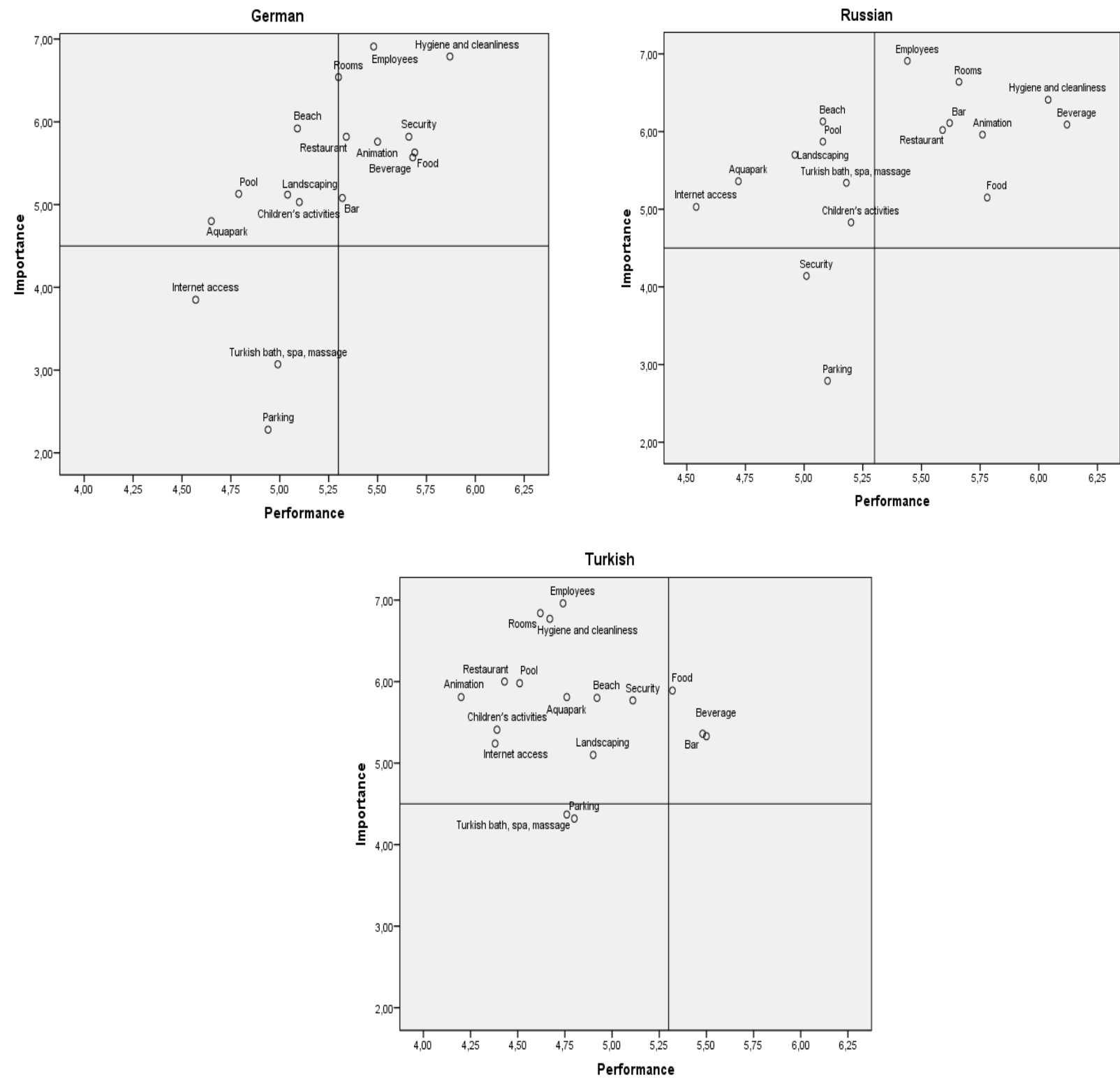

Source: own research

For Turkish tourists, only food and beverage services are included in the context of Keep Up With the Good Work. Within the scope of our research, 17 attributes offered by accommodation businesses were evaluated. In this context, German tourists evaluated 9 out of 14 attributes that they attach importance to as having good performance, Russian tourists assessed 8 out of 15 attributes that they attach importance to as having good performance, while Turkish tourists rated only 3 of the 15 


\section{JOURNAL OF TOURISM AND SERVICES}

Issue 12, volume 22, ISSN 1804-5650 (Online)

www.jots.cz

attributes they attach importance to as having good performance. The high number of items in the Keep Up With the Good Work quadrant and the low number of items in the Concentrate Here quadrant reflect that customer satisfaction is high. Therefore, it can be stated that the customer satisfaction of German and Russian tourists is much higher than that of Turkish tourists.

\subsubsection{Concentrate Here}

Services that German and Russian tourists attach importance to but that are relatively low in performance are similar. Beach services, pool activities, children's activities, landscaping, and aquapark are the services that German and Russian tourists attach importance to, but they are relatively low in performance. Baths, spas, and massage services, as well as internet access, which are not important to German tourists, constitute services that Russian tourists attach importance to but that are considered to have relatively low performance. In particular, the services contained in the Concentrate Here quadrant are entertainment activities during the day, and it is necessary to concentrate on these services to increase customer satisfaction.

For Turkish customers, the result is quite different. Twelve of the 17 services evaluated by Turkish tourists are in the Concentrate Here quadrant. In other words, 12 of the 17 items that customers attributed high importance to have performance values below the desired level. These results show the primary areas that should be improved by the accommodation businesses. Employees' attitude and behavior, hygiene and cleanliness, design, and comfort of the rooms constitute the issues that should primarily be concentrated on in the accommodation businesses to increase the satisfaction of Turkish customers. Similarly, the restaurant, aquapark, pool activities, activities for children, and landscaping of the facility should be further improved to increase Turkish tourists' satisfaction.

\subsubsection{Low Priority and Possible Overkill}

Parking services are located in the Low Priority quadrant, which is of low importance to German and Russian tourists. The majority of German and Russian tourists arrive in the region with package tours, and their transportation to the hotel is carried out by travel agencies. Thus, these tourists do not come to the hotel in their own private vehicles, so they attach low priority to parking and parking services. However, for Turkish tourists, the opposite is the case. The vast majority of Turkish tourists come to the hotel in their own private vehicles, and parking services are therefore regarded as more important. The biggest problem in this regard is that hotel parking lots have a limited capacity. For this reason, customers may have to leave their vehicles outside the hotel's parking lot. Moreover, accommodation businesses in the area offer only limited valet services. On the other hand, our study shows that there were no Possible Overkill services for German, Russian, and Turkish tourists.

\subsection{Satisfaction Relationship With Customer Loyalty}

The regression analysis results in Table 4 suggest that satisfaction with various services offered by accommodation businesses influences customer loyalty. The effect of satisfaction on customer loyalty differs by customer groups. Customer satisfaction had the strongest impact on customer loyalty of Turkish tourists. As much as $75.1 \%$ of the customer loyalty of Turkish tourists is explained by satisfaction with the activities evaluated within the scope of our research, $\mathrm{F}(17,346)=65.344, \mathrm{p}<.05$. It was also found that 5 out of 17 activities had an impact on customer loyalty of 'Turkish tourists. Employees' attitude and behavior $(\beta=.365)$ have the strongest effect on customer loyalty of Turkish tourists, followed by hygiene and cleanliness $(\beta=.187)$, design and comfort of the rooms $(\beta=.155)$, restaurant services $(\beta=.151)$, and animation activities $(\beta=.079)$. These results also show that the strongest effect on Turkish customers' customer loyalty is explained by the activities in the Concentrate Here quadrant in the IPA 


\section{JOURNAL OF TOURISM AND SERVICES}

Issue 12, volume 22, ISSN 1804-5650 (Online)

www.jots.cz

matrix. Consequently, accommodation businesses should focus their resources and opportunities on activities in the Concentrate Here quadrant to increase the customer loyalty of Turkish customers.

Table 4 shows that $68 \%$ of customer loyalty of Russian tourists, $\mathrm{F}(17,393)=49.397, \mathrm{p}<.05$, and $63 \%$ of customer loyalty of German tourists, $\mathrm{F}(17,360)=38.726, \mathrm{p}<.05$, were explained by the satisfaction felt for the activities evaluated within the scope of our research. The strongest effect on the customer loyalty of German and Russian tourists, as on that of Turkish tourists, has employees' attitude and behavior (German $\beta=.599$; Russian $\beta=.450$ ), hygiene and cleanliness (German $\beta=.208$; Russian $\beta=.207$ ), and design and comfort of the rooms (German $\beta=.184$; Russian $\beta=.215$ ). The regression analysis revealed that 15 out of 17 activities affected customer loyalty of Russian tourists and that 14 out of 17 activities affected German tourists. It was concluded that satisfaction with the activities involved in the Keep Up With the Good Work and Concentrate Here quadrants of the IPA matrix has a significant effect on the customer loyalty of German and Russian tourists. These findings support hypotheses $\mathrm{H} 2$ and $\mathrm{H} 3$.

Table 4. The Effects of Satisfaction on Customer Loyalty

\begin{tabular}{|c|c|c|c|c|c|c|c|c|c|}
\hline & \multicolumn{3}{|c|}{ German } & \multicolumn{3}{|c|}{ Russian } & \multicolumn{3}{|c|}{ Turkish } \\
\hline & $\beta$ & $\mathrm{t}$ & $\mathrm{p}$ & $\beta$ & $\mathrm{t}$ & $\mathrm{p}$ & $\beta$ & $\mathrm{t}$ & $\mathrm{p}$ \\
\hline (Constant) & & 10.705 & 0.000 & & 13.109 & 0.000 & & 6.321 & 0.000 \\
\hline $\begin{array}{l}\text { 1.Employees' attitude and } \\
\text { behavior }\end{array}$ & 0.599 & 18.802 & 0.000 & 0.450 & 14.388 & 0.000 & 0.365 & 5.976 & 0.000 \\
\hline 2. Open buffet food variety & 0.110 & 3.373 & 0.001 & 0.171 & 5.846 & 0.000 & 0.006 & 0.223 & 0.823 \\
\hline 3. Beverage variety & 0.130 & 3.988 & 0.000 & 0.184 & 6.193 & 0.000 & 0.037 & 1.370 & 0.172 \\
\hline 4. Restaurant services & 0.134 & 4.180 & 0.000 & 0.113 & 3.747 & 0.000 & 0.151 & 3.584 & 0.000 \\
\hline 5. Bar services & 0.062 & 1.919 & 0.056 & 0.119 & 4.117 & 0.000 & 0.013 & 0.460 & 0.646 \\
\hline 6. Aquapark & 0.130 & 4.009 & 0.000 & 0.178 & 6.065 & 0.000 & 0.024 & 0.885 & 0.377 \\
\hline 7. Pool & 0.064 & 2.013 & 0.045 & 0.054 & 1.742 & 0.082 & 0.041 & 1.092 & 0.276 \\
\hline 8. Animation & 0.129 & 4.033 & 0.000 & 0.054 & 1.680 & 0.094 & 0.079 & 2.093 & 0.037 \\
\hline 9. Turkish bath, spa, massage & 0.088 & 2.775 & 0.006 & 0.072 & 2.464 & 0.014 & 0.015 & 0.560 & 0.576 \\
\hline 10. Beach & 0.060 & 1.856 & 0.064 & 0.143 & 4.761 & 0.000 & 0.011 & 0.415 & 0.678 \\
\hline 11. Children's activities & 0.072 & 2.228 & 0.027 & 0.095 & 3.250 & 0.001 & 0.034 & 1.256 & 0.210 \\
\hline $\begin{array}{l}\text { 12.Design and comfort of the } \\
\text { rooms }\end{array}$ & 0.184 & 5.686 & 0.000 & 0.215 & 6.772 & 0.000 & 0.155 & 2.956 & 0.000 \\
\hline 13. Security services & 0.067 & 2.090 & 0.037 & 0.146 & 4.973 & 0.000 & 0.012 & 0.432 & 0.666 \\
\hline 14. Parking & 0.034 & 1.045 & 0.297 & 0.100 & 3.411 & 0.001 & 0.015 & 0.552 & 0.581 \\
\hline 15. Internet access & 0.084 & 2.633 & 0.009 & 0.096 & 3.317 & 0.001 & 0.001 & 0.028 & 0.977 \\
\hline 16. Hygiene and cleanliness & 0.208 & 6.396 & 0.000 & 0.207 & 6.347 & 0.000 & 0.187 & 3.089 & 0.000 \\
\hline \multirow[t]{2}{*}{ 17. Landscaping of the facility } & 0.098 & 3.072 & 0.002 & 0.141 & 4.888 & 0.000 & 0.021 & 0.777 & 0.437 \\
\hline & $\mathrm{r}^{2}=.646$ & Ad. $R^{2}=.6$ & $\mathrm{~F}=38.726$ & $\mathrm{r}^{2}=.681$ & Ad. $\mathrm{R}^{2}=.60$ & $\mathrm{~F}=49.397$ & $\mathrm{r}^{2}=.763$ & Ad. $R^{2}=.7$ & $\mathrm{~F}=65.344$ \\
\hline
\end{tabular}

Source: own research

\section{Discussion}

Studies in the hospitality sector indicate that gaining new customers is crucial, but efforts to gain new future customers will not be sufficient for success. Therefore, detailed studies are needed on customer satisfaction and customer loyalty (Günaydın, 2015). Although there are previous studies on customer satisfaction in the tourism literature, more work is needed to understand the factors involved in customer satisfaction and customer loyalty. More concretely, an analysis of variables and their interrelationships regarding these factors is necessary for the tourism sector to better understand consumer psychology (Bosque \& Martín, 2008). With the assumption that customer satisfaction factors will also change in changing conditions, such research should be conducted continuously. The reason is 


\section{JOURNAL OF TOURISM AND SERVICES}

Issue 12, volume 22, ISSN 1804-5650 (Online)

www.jots.cz

that customer satisfaction is essential for customer loyalty and business continuity (Kotler et al. 2017; Wilkins, 2010). A sustainable competitive advantage emerges as a result of customer satisfaction and loyalty (Dick \& Basu, 1994).

Additionally, to succeed in service delivery, accommodation businesses need to understand which hotel attributes are important to their market segments and their effect on customer satisfaction and loyalty (Albayrak et al., 2016). Therefore, in our study, the importance and performance (satisfaction) perceptions of customers regarding the services offered by accommodation businesses were examined in terms of customers' nationalities. Determining customer satisfaction for products and services alone is not of high importance. Hence, the effect of satisfaction perceptions on customer loyalty was also examined in relation to different customer groups.

In this study, we found that the performance perceptions regarding hotel services and services that customers attach importance to differ significantly by nationality. As part of the research, 17 attributes offered by accommodation businesses were evaluated. In this context, German tourists rated 9 of the 15 attributes that they attached importance to as having good performance, Russian tourists evaluated 8 of the 15 attributes that they attached importance to as having good performance, and Turkish tourists rated only 3 of the 15 attributes that they attached importance to as having good performance. In particular, the fact that the performance perception scores of Turkish customers are significantly lower than their importance scores shows that the dissatisfaction of Turkish customers is more intense than that of the other nationalities. The small effect size of the difference between the importance and performance scores of German and Russian customers created a positive result in terms of customer satisfaction. According to this result, it would not be practical for hospitality managers to use the results based on average customer satisfaction since it was found that the issues that tourists attach importance to and their perception of performance differ depending on nationality.

The fact that compared to German and Russian customers, Turkish customers regard the performance of hotel services as poor can be explained by the service concept because a very different performance assessment was obtained. German and Russian tourists constitute the main customer group of accommodation businesses in the Alanya region where the research was carried out. Thus, the businesses in this region organized many of the food and beverage and entertainment services according to the interests of this customer group. International employees make up a significant percentage of the employees, especially in the reception, animation, and customer relations departments. In the past five years, the number of Russian tourists coming to Alanya has surpassed the number of German tourists and taken first place. In this context, it can be asserted that there is a need in the region for tourism employees who speak Russian. Accommodation businesses are therefore trying to recruit more Russianspeaking human resources from Russian-speaking countries (Üngüren, 2019). Therefore, accommodation businesses may have introduced a service concept tailored to German and Russian tourists, which are the main customer groups. Our results show that the services provided by the accommodation companies meet the expectations of German and Russian tourists more closely than the expectations of Turkish tourists. However, intercultural empirical studies using moderator variables in different destinations are needed to reach consensus on this subject.

The attributes contained in the Concentrate Here quadrant in the IPA matrix are perceived as very important by customers, but performance levels are regarded as very low. Therefore, this quadrant represents the main weaknesses and threats of products and services to competitiveness (Sever, 2015). Therefore, improvement efforts should concentrate on the attributes of Concentrate Here. In this research, it was found that 12 of the 17 attributes evaluated by Turkish tourists, 7 attributes evaluated by Russian tourists, and 5 attributes evaluated by German tourists were in the Concentrate Here quadrant. Many attributes in this quadrant are similar for German and Russian tourists. Especially for German and Russian tourists, most of the services in this quadrant are seen to consist of recreational activities during the day, and it is essential to focus on these services to increase customer satisfaction. Blesic et al. (2014) and Albayrak (2015a), however, obtained a different result, with recreational services placed in the 


\section{JOURNAL OF TOURISM AND SERVICES}

Issue 12, volume 22, ISSN 1804-5650 (Online)

www.jots.cz

quadrant of low importance and low performance. This result shows that the characteristics that tourists seek in hotel services differ by demographic characteristics, travel type, and purpose. Identifying the attributes in the Concentrate Here quadrant and the factors that reduce performance could be a guide for what improvements should be made. In our research, it was found that for all customer groups, there is no service in the Possible Overkill quadrant. The research findings also suggest that the issues that customers attach importance to should be investigated according to market segments to ensure and increase customer satisfaction in the accommodation businesses.

Customer satisfaction and loyal customer levels are important success indicators of accommodation businesses. In fact, every business aims to increase the number of loyal customers by providing a service that could maximally satisfy its customers. For this reason, hotel managers do their best to find the most important factors that affect customer loyalty. Saunders Hotel Group (in Boston, Connecticut, and Florida) attaches importance to retaining loyal customers and attempts to identify what kind of services can turn their customers into loyal customers (Bowen \& Chen, 2001). Accommodation businesses also try to increase satisfaction and eventually gain loyal customers by communicating intensively with consumers to ensure customer satisfaction, which is crucial for marketing activities (Kotler et al., 2006).

In this study, it was concluded that satisfaction with the services provided in accommodation businesses has a significant effect on customer loyalty and that this effect differs in customer groups. Employees' attitudes and behaviors, hygiene and cleanliness, and the design and comfort of the rooms are the characteristics that German, Russian, and Turkish customers attach the most importance to in terms of hotel services, and these characteristics have the strongest effect on customer loyalty. These identified attributes have also been found in other studies.

Caber and Albayrak (2014) demonstrated that cleanliness was the most important attribute of the criteria that presenior and senior tourists use to select their hotel. Stefko, Fedorko, Bacik, Rigelsky \& Olearova (2020) conducted a study to analyse the quality of services provided and the perception of the hotel according to the point of view of the accommodated clients. They revealed that the hotel equipment and cleanliness have the greatest effect on the polarity of sentiment. Alegre and Garau (2010) examined the reasons for tourists' dissatisfaction at sun and sand tourist destinations in the Balearic Islands, Spain. They revealed that cleanliness and hygiene, accommodation, and safety were among the major attributes of tourist satisfaction. Lee and Lee (2009) concluded that hygiene and cleanliness standards are among the most important factors for Far Eastern tourists visiting Guam Island, Micronesia. Chen, Wang, Luoh, Shih and You (2014) concluded that the cleanliness, comfort, and decoration of hotel rooms could significantly increase customer satisfaction. In their study on tourists coming to the Campania region in Italy, Nisco et al. (2015) established that the comfort and convenience of accommodation businesses, their cleanliness, and the quality of their restaurants and food have an important effect on destination satisfaction.

Mohsin and Lockyer (2010) determined that employees' attitudes and behaviors, courtesy, and professional knowledge are perceived as the most important factors by hotel customers. In their study analyzing the criteria that tourists attach importance to in hotel selection, Caber and Albayrak (2014) suggested that the politeness of staff and friendliness of staff were rated as relatively more important and positioned among the five most important hotel attributes. In other studies, the attitude and behavior of employees towards the customer and their quality and knowledge are among the issues that tourists care about (Albayrak \& Caber, 2011; Bowen \& Chen, 2001; Nisco et al., 2015; Gu \& Ryan, 2008; McCain et al., 2005; Medina-Muñoz, \& Medina-Muñoz, 2014; O’Leary and Deegan 2005; Ren et al., 2016; Xu et al., 2017).

The importance that the customer attributes to a product or service plays an important role in the choice of the product or service (Barsky, 1992). As a matter of fact, determining the attributes of a product or service that are perceived by customers to be most important for customer satisfaction has critical importance in terms of marketing and management. Kozak (2003) investigated the overall 


\section{JOURNAL OF TOURISM AND SERVICES}

Issue 12, volume 22, ISSN 1804-5650 (Online)

www.jots.cz

satisfaction of tourists from different nationalities visiting Mallorca (Spain) and Mugla (Turkey), their repeat visit intention, and their intention to recommend these regions to others. The results of this study revealed that overall tourist satisfaction, their intention to recommend the regions to others, and their repeat visit intention differed between customer groups and between destinations. The main task of the management is to establish strong relationships with guests, to constantly monitor changes in consumers' demands, and to establish service standards that reflect the demands of customers with a well-planned and well-designed service environment (Blešić et al., 2014). Defining the roles of hotel services in customer satisfaction and loyalty is important for the success of businesses. The results obtained in our study reveal that the importance given by the customers to the service attributes and how the business performs related to these services should be considered according to customer groups to continuously improve the service quality of accommodation businesses and to ensure customer satisfaction and loyalty. Our results also have some important implications for practitioners and academics working in the field of marketing and strategic management. Businesses aim to provide customer satisfaction and to turn new customers into loyal customers by attempting to offer products and services appropriate for their customer profile. The results of our research reveal which products should be developed according to market groups and which products and services are important. Businesses try to achieve a competitive advantage with strategic management practices. A sustainable competitive advantage emerges as a result of customer satisfaction and loyalty (Dick \& Basu, 1994). The results obtained in this study indicate that satisfaction factors affecting customer loyalty differ depending on nationality. Accordingly, our research findings contribute to how customer loyalty can be improved based on market groups.

\section{Conclusion}

Customer loyalty and customer satisfaction are among the most important factors that provide a competitive advantage for businesses. Although many studies about customer satisfaction and customer loyalty are classified according to gender and age, few studies classify according to nationalities (Martin, Rudchenko \& Sanchez-Rebull, 2020). In this context, our research has two main objectives. The primary objective of our research is to determine the importance and performance perceptions of the services provided by the hotels according to the nationalities of the customers using the IPA model and to compare the perceptions of importance-performance according to nationality. The second main objective of our study is to determine the effect of satisfaction perceptions regarding hotel services on customer loyalty according to customer groups. The findings, obtained as a result of the study, reveal that customers' importance to hotel features differs according to their nationalities. Another result of the study is that customer satisfaction significantly affects customer loyalty, but the effects of factors affecting customer loyalty differ significantly according to customers' nationalities. This study suggests that hotel services and products should be diversified according to the market groups and nationalities. Findings provide a new perspective for the managers about how businesses develop a service strategy to achieve competitive advantage.

As for limitations and Directions for Future Research, it is impossible to generalize the results obtained in the study because the research data were collected through convenience sampling with nonrandom sampling methods. Also, the research data were collected only from five-star hotels, and other accommodation facilities could not be included in the study because of time and budget constraints. In this study, the services offered by hotels were examined without comparison with their competitors. It is necessary to understand how customers perceive product or service characteristics, importance, and performance compared to other competitors to succeed in business. In a competitive hotel environment, hoteliers must examine the strengths and weaknesses of the products or services they offer and accurately identify their importance and performance (Chu \& Choi, 2000). Besides, customer satisfaction refers to a situation that is necessary but not sufficient for loyalty (Shoemaker \& Lewis, 1999). Even when a high quality of service is provided and a customer is satisfied, this does not necessarily mean that the customer 


\section{JOURNAL OF TOURISM AND SERVICES}

Issue 12, volume 22, ISSN 1804-5650 (Online)

www.jots.cz

will return (Cobanoglu et al., 2011). In this context, investigating the failure of the customer to return to a business where they received high-quality service and were satisfied could be useful in terms of accurate and effective use of business resources. The COVID-19 outbreak that occurred in Wuhan, in China's Hubei province, in the last weeks of December 2019 had a devastating effect on the tourism and travel industry in all countries (Neuburger \& Egger, 2020). Scientific research has shown that epidemics have negative effects on the travel behavior of tourists because epidemics negatively affect the health and safety perception of tourists (Ritchie \& Jiang, 2019). In this context, investigating how the COVID-19 outbreak affects the priorities and expectations of tourists regarding hotel services will contribute to determining which attributes accommodation businesses should pay attention to in providing services during an epidemic.

\section{References}

1. Abooali, G., Omar, S.I., \& Mohamed, B. (2015). The importance and performance of a destination's attributes on senior tourists' satisfaction. International Journal of Asian Social Science, 5(6), 355-368. http://doi.org/10.18488/journal.1/2015.5.6/1.6.355.368

2. Agyeiwaah, E., Adongo, R., Dimache, A., \& Wondirad, A. (2016). Make a customer, not a sale: Tourist satisfaction in Hong Kong. Tourism Management, 57, 68-79. https://doi.org/10.1016/j.tourman.2016.05.014

3. Aksoy, L., Buoye, A., Aksoy, P., Larivière, B., \& Keiningham, T. L. (2013). A cross-national investigation of the satisfaction and loyalty linkage for mobile telecommunications services across

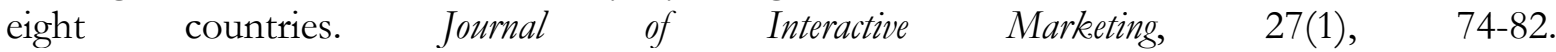
http://dx.doi.org/10.1016/j.intmar.2012.09.003

4. Al-Balushi, M., \& Atef, T. (2013). Online social networks impact on potential travellers' tourism and hospitality choices. European Journal of Tourism, Hospitality and Recreation, 4(1), 69-102.

5. Albayrak, T. (2015a). A Comparison of the Symmetric and Asymmetric Relationships between Product Attributes' Performance and Customer Satisfaction. Anatolia: Turizm Arastormalar Dergisi, 26(1), 17-28. https://doi.org/10.17123/atad.vol26iss131923

6. Albayrak, T. (2015b). Importance Performance Competitor Analysis (IPCA): A study of hospitality companies. International Journal of Hospitality Management, 48, 135-142. https://doi.org/10.1016/j.ijhm.2015.04.013

7. Albayrak, T., \& Caber, M. (2011). Importance-Performance analysis: A sample about destination management. Ege Academic Review, 11(4), 627-638.

8. Albayrak, T., Caber M., \& Bideci, M. (2016). Identification of hotel attributes for senior tourists by using Vavra's importance grid. Journal of Hospitality and Tourism Management, 29, 17-23. https://doi.org/10.1016/j.jhtm.2016.05.004

9. Alegre, J., \& Garau, J. (2010). Tourist satisfaction and dissatisfaction. Annals of Tourism Research, 37 (1), 52-73. https://doi.org/10.1016/j.annals.2009.07.001

10. Ali, F., Kim, W. G., Li, J., \& Jeon, H. M. (2018). Make it delightful: Customers' experience, satisfaction and loyalty in Malaysian theme parks. Journal of Destination Marketing \& Management, 7 , 1-11. http://dx.doi.org/10.1016/j.jdmm.2016.05.003

11. ALTSO (2020). Alanya Economic Report, Retrieved from https://www.altso.org.tr/yayinlarimiz/alanya-ekonomik-rapor/alanya-ekonomik-rapor-2019/ (15.10.2020).

12. Assaf, A. G., \& Magnini, V. (2012). Accounting for customer satisfaction in measuring hotel efficiency: Evidence from the US hotel industry. International Journal of Hospitality Management, 31(3), 642-647. https://doi.org/10.1016/j.ijhm.2011.08.008

13. Azzopardi, E., \& Nash, R. (2013). A critical evaluation of importance-performance analysis. Tourism Management, 35, 222-233. https://doi.org/10.1016/j.tourman.2012.07.007 


\section{JOURNAL OF TOURISM AND SERVICES}

Issue 12, volume 22, ISSN 1804-5650 (Online)

www.jots.cz

14. Barsky, J. (1992). Customer satisfaction in hotel industry: Meaning and measurement. Hospitality Research Journal, 16(1), 51-73. https://doi.org/10.1177/109634809201600105

15. Blešić, I., Popov-Raljić, J., Uravić, L., Stankov, U., Đeri, L., Pantelić, M., \& Armenski, T. (2014). An importance-performance analysis of service quality in spa hotels. Economic Research-Ekonomska Istraživanja, 27(1), 483-495. https://doi.org/10.1080/1331677X.2014.967537

16. Bobalca, C., Gatej, C. \& Ciobanu, O. (2012). Developing a scale to measure customer loyalty. Procedia Economics and Finance, 3, 623-628. https://doi.org/10.1016/S2212-5671(12)00205-5

17. Bodet, G., Anaba, V., \& Bouchet, P. (2017). Hotel attributes and consumer satisfaction: A cross-country and cross-hotel study. Journal of Travel \& Tourism Marketing, 34(1), 52-69.

18. Bolton, R.N., Lemon, K.N. \& Verhoef, P.C. (2004). The Theoretical Underpinnings of Customer Asset Management: A Framework and Propositions for Future Research. Journal of the Academy of Marketing Science, 32, 271-292. https://doi.org/10.1177/0092070304263341

19. Bosque, I. R., \& Martín, H. S. (2008). Tourist satisfaction a cognitive-affective model. Annals of Tourism Research, 35(2), 551-573.

20. Bosque, I.R., \& Martín, H.S. (2008). Tourist satisfaction a cognitive-affective model. Annals of Tourism Research, 35(2), 551-573. https://doi.org/10.1016/j.annals.2008.02.006

21. Bowen, J. T., \& Chen, S. (2001). The relationship between customer loyalty and customer satisfaction. International Journal of Contemporary Hospitality Management, 13(5), 213-217. https://doi.org/10.1108/09596110110395893

22. Bowen, J.T. \& Shoemaker, S. (1998). Loyalty: A strategic commitment. Cornell Hotel and Restaurant Administration Quarterly, 39 (1), 12-25. https://doi.org/10.1177/001088049803900104

23. Caber, M., \& Albayrak, T. (2014). Does the importance of hotel attributes differ for senior tourists? A comparison of three markets. International Journal of Contemporary Hospitality Management, 26(4), 610-628. https://doi.org/10.1108/IJCHM-02-2013-0103

24. Cahill, D. L., Goldsby, T. J., Knemeyer, A.M., \& Wallenburg, C. M. (2010). Customer loyalty in logistics outsourcing relationships: an examination of the moderating effects of conflict frequency. Journal of Business Logistics, 31(2), 253-277.

25. Callan, R.J., \& Bowman, L. (2000). Selecting a hotel and determining salient quality attributes: a preliminary study of mature British travellers. International Journal of Tourism Research, 2, 97-118. https://doi.org/10.1002/(SICI)1522-1970(200003/04)2:2<97::AID-JTR190>3.0.CO;2-1

26. Ceylan, D., Cizel, B., \& Karakas, H. (2020). Cross-nationality importance performance analysis of Middle East all-inclusive mass tourism destination image. Journal of Hospitality and Tourism Insights, Vol. ahead-of-print No. ahead-of-print. https://doi.org/10.1108/JHTI-06-2020-0108

27. Chen, W.Y., Wang, K.C., Luoh, H.F., Shih, J.F., \& You, Y.S. (2014). Does a friendly hotel room increase senior group package tourists' satisfaction? A field experiment. Asia Pacific Journal of Tourism Research, 19 (8), 950-970. https://doi.org/10.1080/10941665.2013.833123

28. Chen, Y. (2008). Herd behavior in purchasing books online. Computers in Human Behavior, 24 (5), 1977-1992. doi:10.1016/j.chb.2007.08.004

29. Cheng, B.L., Gan, C.C., Imrie, B.C. \& Mansori, S. (2019). Service recovery, customer satisfaction and customer loyalty: evidence from Malaysia's hotel industry. International Journal of Quality and Service Sciences, 11(2), 187-203. https://doi.org/10.1108/IJQSS-09-2017-0081

30. Chu, R. K. S., \& Choi, T. (2000). An importance-performance analysis of hotel selection factors in the Hong Kong hotel industry: A comparison of business and leisure travellers. Tourism Management, 21(4), 363-377. http://dx.doi.org/10.1016/S0261-5177(99)00070-9

31. Cobanoglu, C., Berezina, K., Kasavana, M. L., \& Erdem, M. (2011). The Impact of Technology Amenities on Hotel Guest Overall Satisfaction. Journal of Quality Assurance in Hospitality \& Tourism, 12(4), 272-288. http://dx.doi.org/10.1080/1528008X.2011.541842 


\section{JOURNAL OF TOURISM AND SERVICES}

Issue 12, volume 22, ISSN 1804-5650 (Online)

www.jots.cz

32. Cvelbar, L.K. \& Dwyer, L. (2013). An importance-performance analysis of sustainability factors for long-term strategy planning in Slovenian hotels. Journal of Sustainable Tourism, 21(3), 487-504. http://dx.doi.org/10.1080/09669582.2012.713965

33. Davras, Ö. \& Caber, M. (2019). Analysis of hotel services by their symmetric and asymmetric effects on overall customer satisfaction: A comparison of market segments. International Journal of Hospitality Management, 81, 83-93. http://dx.doi.org/10.1016/j.ijhm.2019.03.003

34. Deng, J. \& Pierskalla, C. D. (2018). Linking Importance-Performance Analysis, Satisfaction, and $\begin{array}{lllll}\text { Loyalty: A Study of Savannah, GA. Sustainability, } & 10(3), 704 .\end{array}$ http://dx.doi.org/10.3390/su10030704

35. Deng, W. J., Yeh, M. L. \& Sung, M. L. (2013). A customer satisfaction index model for international tourist hotels: Integrating consumption emotions into the American Customer Satisfaction Index. International Journal of Hospitality Management, 35, 133-140. http://dx.doi.org/10.1016/j.ijhm.2013.05.010

36. Dick, A.S. \& Basu, K. (1994). Customer loyalty: Toward an integrated conceptual framework. Journal of the Academy of Marketing Science, 22(2), 99-113. http://dx.doi.org/10.1177/0092070394222001

37. El-Adly, M. I. (2019). Modelling the relationship between hotel perceived value, customer satisfaction, and customer loyalty. Journal of Retailing and Consumer Services, 50, 322-332. http://dx.doi.org/10.1016/j.jretconser.2018.07.007

38. El-Adly, M.I. (2019). Modelling the relationship between hotel perceived value, customer satisfaction, and customer loyalty. Journal of Retailing and Consumer Services, 50, 322-332. http://dx.doi.org/10.1016/j.jretconser.2018.07.007

39. El-Aldy, M. I. \& Eid, R. (2016). An empirical study of the relationship between shopping environment, customer perceived value, satisfaction, and loyalty in the UAE malls context. Journal of Retailing and Consumer Services, 31, 217-227. https://doi.org/10.1016/j.jretconser.2016.04.002

40. Emir, O. (2013). A multi-national satisfaction analysis: An application on tourists in Antalya. Tourism: An International Interdisciplinary Journal, 61(4), 347-359.

41. Erjavec, H. Š., Dmitrović, T., \& Povalej Bržan, P. (2016). Drivers of customer satisfaction and loyalty in service industries. Journal of Business Economics and Management, 17(5), 810-823. http://dx.doi.org/10.3846/16111699.2013.860614

42. Faullant, R., Matzler, K. \& Füller, J. (2008). The impact of satisfaction and image on loyalty: the case of Alpine ski resorts. Managing Service Quality: An International Journal, 18 (2), 163-178. https://doi.org/10.1108/09604520810859210

43. Forozia, A., Zadeh, M.S. \& Gilani, M.H.N. (2013). Customer Satisfaction in Hospitality Industry: Middle East Tourists at 3star Hotels in Malaysia. Research Journal of Applied Sciences, Engineering and Technology, 5(17), 4329-4335. http://dx.doi.org/10.19026/rjaset.5.4425

44. Gallarza, M. G., Arteaga, F., \& Gil-Saura, I. (2019). Customer value in tourism and hospitality: Broadening dimensions and stretching the value-satisfaction-loyalty chain. Tourism Management Perspectives, 31, 254-268. http://dx.doi.org/10.1016/j.tmp.2019.05.011

45. Gerpott, T. J., Rams, W., \& Schindler, A. (2001). Customer retention, loyalty, and satisfaction in the German mobile cellular telecommunications market. Telecommunications policy, 25(4), 249-269.

46. Gould, G. (1995). Why it is customer loyalty that counts (and how to measure it). Managing Service Quality, 7(4), 4-26. http://dx.doi.org/10.1108/09604529510796304

47. Grewal, D., Roggeven, A. L. \& Nordfalt, J. (2017). The Future of Retailing. Journal of Retailing, 93, $1-6$.

48. Griffin, T., \& Edwards, D. (2012). Importance - performance analysis as a diagnostic tool for urban destination managers. Anatolia - An International Journal of Tourism and Hospitality Research, 23(1), 32-48. http://dx.doi.org/10.1080/13032917.2011.653630 


\section{JOURNAL OF TOURISM AND SERVICES}

Issue 12, volume 22, ISSN 1804-5650 (Online)

www.jots.cz

49. Gu, H., \& Ryan, C. (2008). Chinese clientele at Chinese hotels-Preferences and satisfaction. International Journal of Hospitality Management,27(3), 337-345. http://dx.doi.org/10.1016/j.ijhm.2007.10.005

50. Günaydin, Y. (2015). The effect of service quality on customer loyalty: A sample of Aegean Dream Hotel. International Journal of Social Sciences and Education Research, 1(1), 16-34. https://doi.org/10.24289/ijsser.106396

51. Hoare, R. J. \& Butcher, K. (2008). Do Chinese cultural values affect customer satisfaction/loyalty?. International Journal of Contemporary Hospitality Management, 20 (2), 156-171. http://dx.doi.org/10.1108/09596110810852140.

52. Jeong, M. \& Oh, H. (1998). Quality function deployment: An extended framework for service quality and customer satisfaction in the hospitality industry. International Journal of Hospitality Management, 17 (4), 375-390

53. Jin, X., Qi, S., \& Chiang, C. H., (2008). A cross-sector evaluation of service quality in the tourism industry of Hong Kong: Importance vs. performance. Journal of China Tourism Research, 4(3-4), 319-335. http://dx.doi.org/10.1080/19388160802505754

54. Kandampully, J. \& Suhartanto, D. (2000). Customer loyalty in the hotel industry: The role of customer satisfaction and image. International Journal of Contemporary Hospitality Management, 12 (6), 346-351. http://dx.doi.org/10.1108/09596110010342559

55. Kandampully, J. \& Suhartanto, D. (2003). The Role of Customer Satisfaction and Image in Gaining Customer Loyalty in the Hotel Industry. Journal of Hospitality \& Leisure Marketing, 10(1-2) 3-25.

56. Kasiri, L.A., Cheng, K.T.G., Sambasivan, M., \& Sidin, S.M. (2017). Integration of standardization and customization: Impact on service quality, customer satisfaction, and loyalty. Journal of Retailing and Consumer Services, 35, 91-97. http://dx.doi.org/10.1016/j.jretconser.2016.11.007

57. Kim, J. J., Lee, Y., \& Han, H. (2019). Exploring competitive hotel selection attributes among guests: An importance-performance analysis. Journal of Travel \& Tourism Marketing, 36(9), 9981011. https://doi.org/10.1080/10548408.2019.1683484

58. Kim, M., Vogt, C. A., \& Knutson, B. J. (2015). Relationships among customer satisfaction, delight, and loyalty in the hospitality industry. Journal of Hospitality \& Tourism Research, 39(2), 170 197. http://dx.doi.org/10.1177/1096348012471376

59. Kline, R. B. (2011). Principles and practice of structural equation modeling (3rd ed.). New York, NY: Guilford Press.

60. Kobylanski, A. (2012). Attributes and consequences of customer satisfaction in tourism industry: The case of Polish travel agencies. Journal of Service Science, 5(1), 29-42. http://dx.doi.org/10.19030/jss.v5i1.6939

61. Kotler, P., Bowen, J. T., Makens, J. C. \& Baloğlu, S. (2017). Marketing for Hospitality and Tourism (7. ed.). Upper Saddle River, NJ: Pearson Prentice Hall.

62. Kotler, P., Bowen, J., \& Makens, J. (2006). Marketing for Hospitality and Tourism, 4th ed. Upper Saddle River, NJ: Prentice Hall.

63. Kozak, M. (2003). Measuring comparative destination performance: A study in Spain and Turkey. Journal of Tourism and Travel Marketing, 13 (3), 83-110.

64. Kuo, C. M. (2007). The importance of hotel employee service attitude and the satisfaction of international tourists. The Service Industries Journal, 27(8), 1073-1085. https://doi.org/10.1080/02642060701673752

65. Lahap, J., Ramli, N. S., Said, N. M., Radzi, S. M., \& Zain, R. A. (2016). A study of brand image towards customer's satisfaction in the Malaysian hotel industry. Procedia-Social and Behavioral Sciences, 224(2016), 149-157. 


\section{JOURNAL OF TOURISM AND SERVICES}

Issue 12, volume 22, ISSN 1804-5650 (Online)

www.jots.cz

66. Lee, G. \& Lee, C. K. (2009). Cross-cultural comparison of the image of Guam perceived by Korean and Japanese Leisure Travelers: Importance-Performance Analysis. Tourism Management, 30(6), 922-931. http://dx.doi.org/10.1016/j.tourman.2008.11.013

67. Lee, S., \& Kim, D. Y. (2020). The BRAND tourism effect on loyal customer experiences in luxury hotel: The moderating role of psychological ownership. Tourism Management Perspectives, 35, 100725. https://doi.org/10.1016/j.tmp.2020.100725

68. Li, H., Ye, Q. \& Law R. (2013). Determinants of Customer Satisfaction in the Hotel Industry: An Application of Online Review Analysis. Asia Pacific Journal of Tourism Research, 18 (7), 784-802, http://dx.doi.org/10.1080/10941665.2012.708351

69. Liat, C.B., Mansori, S., Chuan, G.C., \& \& Imrie, B.C. (2017) Hotel Service Recovery and Service Quality: Influences of Corporate Image and Generational Differences in the Relationship between Customer Satisfaction and Loyalty, Journal of Global Marketing, 30(1), 42-51 https://doi.org/10.1080/08911762.2016.1262932

70. Lin, J. S. C., \& Wu, C. Y. (2011). The role of expected future use in relationship based service retention. Managing Service Quality, 21(5), 535-551. http://dx.doi.org/10.1108/09604521111159816

71. Maroco, A. L., \& Maroco, J. (2013). Service Quality, Customer Satisfaction and Loyalty in 4- and 5-Star Hotels. European Journal of Tourism, Hospitality and Recreation, 4(3),119-145.

72. Maroco, A.L., \& Maroco, J. (2013). Service quality, customer satisfaction and loyalty in 4-and 5Star Hotels. European Journal of Tourism, Hospitality and Recreation, 4(3), 119-145.

73. Martenson, R. (2007). Corporate brand image, satisfaction and store loyalty: A study of the store as a brand, store brands and manufacturer brands. International Journal of Retail \& Distribution Management, 35(7), 544-555.

74. Martilla, J. A., \& James, J. C. (1977). Importance-performance analysis. Journal of Marketing, 41(1), 77-79. http://dx.doi.org/10.1177/002224297704100112

75. Martín, J. C., Rudchenko, V., \& Sánchez-Rebull, M. V. (2020). The Role of Nationality and Hotel Class on Guests' Satisfaction. A Fuzzy-TOPSIS Approach Applied in Saint Petersburg. Administrative Sciences, 10(3), 68.

76. McCain, S. L. C., Jang, S. C. S., \& Hu, C. (2005). Service quality gap analysis toward customer loyalty: practical guidelines for casino hotels. Hospitality Management, 24, 465-472. http://dx.doi.org/10.1016/j.ijhm.2004.09.005

77. McDowall, S., \& Ma, E. (2010). An Analysis of 'Tourists' Evaluation of Bangkok's Performance, Their Satisfaction, and Destination Loyalty: Comparing International Versus Domestic Thai Tourists. Journal of Quality Assurance in Hospitality \& Tourism, 11(4), 260-282, https://doi.org/10.1080/1528008X.2010.504181

78. Medina-Muñoz, D.R., \& Medina-Muñoz, R.D. (2014). The attractiveness of wellness destinations: An importance-performance-satisfaction Approach. International Journal of Tourism Research, 16(6), 521-533. http://dx.doi.org/10.1002/jtr.1944

79. Mohammed, A., \& Rashid, B. (2018). A conceptual model of corporate social responsibility dimensions, brand image, and customer satisfaction in Malaysian hotel industry. Kasetsart Journal of Social Sciences, 39(2), 358-364. http://dx.doi.org/10.1016/j.kjss.2018.04.001

80. Mohsin, A. \& Lockyer, T. (2010). Customer perceptions of service quality in luxury hotels in New Delhi, India: an exploratory study. International Journal of Contemporary Hospitality Management, 22(2), 160-173. http://dx.doi.org/10.1108/09596111011018160

81. Mohsin, A., Rodrigues, H., \& Brochado, A. (2019). Shine bright like a star: Hotel performance and guests' expectations based on star ratings. International Journal of Hospitality Management, 83, 103-114. http://dx.doi.org/10.1016/j.ijhm.2019.04.012 


\section{JOURNAL OF TOURISM AND SERVICES}

Issue 12, volume 22, ISSN 1804-5650 (Online)

www.jots.cz

82. Neuburger, L. \& Egger, R. (2020). Travel risk perception and travel behaviour during the COVID-19 pandemic 2020: A case study of the DACH region. Current Issues in Tourism, http://dx.doi.org/10.1080/13683500.2020.1803807

83. Nisar, M. T. \& Pranhakar, G. (2017). What factors determine e-satisfaction and consumer spending in e-commerce retailing?. Journal of Retailing and Consumer Services, 39, 135-144. http://dx.doi.org/10.1016/j.jretconser.2017.07.010

84. Nisco, A., Riviezzo, A., \& Napolitano, M. R. (2015). An Importance-Performance analysis of tourist satisfaction at destination level: evidence from Campania (Italy). European Journal of Tourism Research, 10, $64-75$.

85. Nobar, H. B. K., \& Rostamzadeh, R. (2018). The impact of customer satisfaction, customer experience and customer loyalty on brand power: empirical evidence from hotel industry. Journal of Business Economics and Management, 19(2), 417-430. https://doi.org/10.3846/jbem.2018.5678

86. Nunkoo, R., Teeroocengadom, V., Ringle, M. C. \& Sunnassee, V. (2020). Service quality and customer satisfaction: The moderating effects of hotel star rating. International Journal of Hospitality Management, 102414, https://doi.org/10.1016/j.ijhm.2019.102414.

87. O'Leary, S., \& Deegan, J. (2005). Ireland's image as a tourism destination in France: Attribute importance and performance. Journal of Travel Research, 43(3), 247-256. http://dx.doi.org/10.1177/0047287504272025

88. Oh, H. \& Kim, K. (2017). Customer satisfaction, service quality, and customer value: years 20002015. International Journal of Contemporary Hospitality Management, 29 (1), 2-29. http://dx.doi.org/10.1108/IJCHM-10-2015-0594

89. Oh, H. (1999). Service quality, customer satisfaction, and customer value: A holistic perspective. International Journal of Hospitality Management, 18(1), 67-82.

90. Oliver, R. L. (1997). Satisfaction: A Behavioral Perspective on the Consumer. McGraw- Hill, NY. http://dx.doi.org/10.4324/9781315700892

91. Olorunniwo, F., Hsu, M. K., \& Udo, G. J. (2006). Service quality, customer satisfaction, and behavioral intentions in the service factory. Journal of Services Marketing, 20(1), 59-72.

92. Pantouvakis, A. (2013) The moderating role of nationality on the satisfaction loyalty link: evidence from the tourism industry. Total Quality Management \& Business Excellence, 24(9-10), 1174-1187. https://doi.org/10.1080/14783363.2013.776758

93. Poon, W., \& Lock-Teng Low, K. (2005). Are travellers satisfied with Malaysian hotels?. International Journal of Contemporary Hospitality Management, 17(3), 217227. https://doi.org/10.1108/09596110510591909

94. Reichheld, F. F. (1996). The-loyalty effect: The hidden force behind growth, profits, and lasting value. Harvard Business School Press, Boston, MA.

95. Reichheld, F., \& Sasser, W. E. (1990). Zero defections: quality comes to services. Harvard Business Review, 68, 105-111.

96. Ren, L., Qiu, H., Wang, P., \& Lin, P. M. (2016). Exploring customer experience with budget hotels: Dimensionality and satisfaction. International Journal of Hospitality Management, 52, 13-23. http:/ /dx.doi.org/10.1016/j.ijhm.2015.09.009

97. Rial, A., Rial, J., Varela, J., \& Real, E. (2008). An application of importance-performance analysis (IPA) to the management of sport centres. Managing Leisure, 13(3-4), 179-188. http://dx.doi.org/10.1080/13606710802200878

98. Ritchie, B. W., \& Jiang, Y. (2019). A review of research on tourism risk, crisis and disaster management: Launching the annals of tourism research curated collection on tourism risk, crisis and disaster management. Annals of Tourism Research, 79, 102812. http://dx.doi.org/10.1016/j.annals.2019.102812

99. Rust, R.T., Chung, T.S., (2006). Marketing models of service and relationships. Marketing Science, 25 (6), 560-580. http://dx.doi.org/10.1287/mksc.1050.0139 


\section{JOURNAL OF TOURISM AND SERVICES}

Issue 12, volume 22, ISSN 1804-5650 (Online)

www.jots.cz

100. Ryu, K., Lee, H., \& Kim, G.W. (2012). The influence of the quality of the physical environment, food, and service on restaurant image, customer perceived value, customer satisfaction, and behavioral intentions. International Journal of Contemporary Hospitality Management, 24(2), 200-223. http://dx.doi.org/10.1108/09596111211206141

101. Sánchez-Franco, M. J., Navarro-García, A., \& Rondán-Cataluña, F. J. (2019). A naive Bayes strategy for classifying customer satisfaction: A study based on online reviews of hospitality services. Journal of Business $\quad$ Research, 101, 499-506. http://dx.doi.org/10.1016/j.jbusres.2018.12.051

102. Sarwar, M. Z., Abbasi, K. S., \& Pervaiz, S. (2012). The effect of customer trust on customer loyalty and customer retention: A moderating role of cause related marketing. Global Journal of Management and Business Research, 12(6), 26-36.

103. Sever, I. (2015). Importance-performance analysis: A valid management tool?. Tourism Management, 48, 43-53. http://dx.doi.org/10.1016/j.tourman.2014.10.022

104. Sharma, S., Abebe, L., \& Kelkay, S. (2018). Attractiveness of Gambella as a tourist destination: An Importance-Performance Analysis. KIMI Hospitality Research Journal, 3(1), 7-12.

105. Shi, Y., Prentice, C., \& He, W. (2014). Linking service quality, customer satisfaction and loyalty in casinos, does membership matter?. International Journal of Hospitality Management, 40, 8191. http://dx.doi.org/10.1016/j.ijhm.2014.03.013

106. Shoemaker, S., \& Lewis, R. C. (1999). Customer loyalty: the future of hospitality marketing. International Journal of Hospitality Management, 18(4), 345-370. http://dx.doi.org/10.1016/S0278-4319(99)00042-0

107. Som, A. P. M., Shirazi, S. F. M., Marzuki, A. \& Jusoh, J. (2011). A critical analysis of tourist satisfaction and destination loyalty. Journal of Global Management, 2(1), 178-183.

108. Stefko, R., Fedorko, R., Bacik, R., Rigelsky, M. \& Olearova, M. (2020). Effect of service quality assessment on perception of TOP hotels in terms of sentiment polarity in the Visegrad group countries. Oeconomia Copernicana, 11(4), 721-742. https://doi.org/10.24136/oc.2020.029

109. Tabachnick, B. G., \& Fidell. L. S. (2013). Using multivariate statistics (6th Edition). Boston: Pearson Education.

110. Tanford, S. \& Jung, S. (2017). Festival attributes and perceptions: A meta-analysis of relationships with satisfaction and loyalty. Tourism Management, 61, 209-220. http://dx.doi.org/10.1016/j.tourman.2017.02.005

111.Taplin, R. (2013). The influence of competition on visitor satisfaction and loyalty. Tourism Management, 36, 238-246. http://dx.doi.org/10.1016/j.tourman.2012.12.012

112. Tsaur, S. H., Chiu, Y. C., \& Huang, C. H. (2002). Determinants of guest loyalty to international tourist hotels - a neural network approach. Tourism Management, 23(4), 397-405. http://dx.doi.org/10.1016/S0261-5177(01)00097-8

113. Üngüren, E. (2019). Determining the discrimination level of personality traits of frontline employees on job performances. Journal of Mehmet Akif Ersoy University Economics and Administrative Sciences, 6 (3), 768-795. https://doi.org/10.30798/makuiibf.586959

114. Unguren, E., \& Arslan, S. (2021). The effect of role ambiguity and role conflict on job performance in the hotel industry: the mediating effect of job satisfaction. Tourism \& Management Studies, 17(1), 45-58, https://doi.org/10.18089/tms.2021.170104

115. Wilkins, H. (2010). Using importance-performance analysis to appreciate satisfaction in hotels. Journal of Hospitality Marketing \& Management, 19(8), 866-888. http://dx.doi.org/10.1080/19368623.2010.514554

116. Xu, X., Wang, X., Li, Y., \& Haghighi, M. (2017). Business intelligence in online customer textual reviews: Understanding consumer perceptions and influential factors. International Journal of Information Management, 37(6), 673-683. http://dx.doi.org/10.1016/j.ijinfomgt.2017.06.004 


\section{JOURNAL OF TOURISM AND SERVICES}

Issue 12, volume 22, ISSN 1804-5650 (Online)

www.jots.cz

117. Yang, Y., Liu, X., Jing, F., \& Li, J. (2014). How does perceived value affect travelers' satisfaction and loyalty. Social Behavior and Personality, 42(10), 1733-1744. https:// doi.org/10.2224/sbp.2014.42.10.1733

118. Yoo, S. J. \& Chang, Y. J. (2005). An exploratory research on the store image attributes affecting its store loyalty. Seoul Journal of Business. 11(1),19-41.

119. Yoon, Y., \& Uysal, M. (2005). An examination of the effects of motivation and satisfaction on destination loyalty: A structural model. Tourism management, 26(1), 45-56. http://dx.doi.org/10.1016/j.tourman.2003.08.016

\section{Brief description of Authors:}

\section{Engin Unguren, Assistant Proffessor}

ORCID ID: https://orcid.org/0000-0002-7223-2543

Alanya Alaaddin Keykubat University, Faculty of Economics and Administrative Sciences, Department of Business Administration, Alanya-Turkey, engin.unguren@alanya.edu.tr

Dr. Engin Unguren works as a assistant professor at Alanya Alaaddin Keykubat University. He completed his $\mathrm{PhD}$ at Akdeniz University, Tourism Management Programme. His main research interests include tourist behavior, sociology of tourism and organizational psychology. He is serving as an reviewer of several international journals. He has authored research articles and books related to tourism and organizational psychology.

\section{Salih Tellioglu, Assistant Proffessor}

ORCID ID: https://orcid.org/0000-0001-6510-110X

Hotel, Restaurant and Catering Services Department, ALTSO Tourism Vocational School, Alanya Alaaddin Keykubat University. Kestel Mahallesi Üniversite Caddesi No: 86, 07450 Alanya-Antalya Turkey.salih.tellioglu@alanya.edu.tr

Salih Tellioglu is an assistant professor at the ALTSO Tourism Vocational School. He focuses on hotel management, tourism marketing, sustainable tourism and supplier selection.

\section{Nazl1 Türker, Research Assistant}

ORCID ID: https://orcid.org/0000-0003-0318-1700

Institute of Graduate Studies, Department of Business Administration, Alanya Alaaddin Keykubat University, Kestel District, University Street, FEAS Building Floor 2, Alanya / Antalya, TURKEY. https://www.alanya.edu.tr/

Nazlı Türker is a research assistant in the Institute of Graduate Studies and Faculty of Economics and Administrative Sciences. She is a doctoral student in the Department of Business Administration. She was graduated from the Department of Sociology in Middle East Technical University (METU), Turkey. Her scientific research is primarily focused on organizational behavior, management and organization as well as organizational theory. 